\title{
ENRABAMENTO, CURA E PROTEÇÃO: COSMOLOGIAS DO CABOCLO ATAÍDE NO NORDESTE PARAENSE
}

\author{
Jerônimo da Silva e Silva ${ }^{12}$ \\ Flávio Leonel Abreu da Silveira ${ }^{12}$ \\ ${ }^{1}$ Universidade Federal do Sul e Sudeste do Pará, Marabá, PA, Brasil \\ ${ }^{2}$ Universidade Federal do Pará, Belém, PA, Brasil
}

Pau de arraia \& cabaço amansador: apresentação

"O pau do Ataíde, pro senhor ter uma ideia, é a mesma coisa que o ferrão de uma arraia [...] ali não tem quem aguente a dor [...], é de encher as calça mesmo, pra ver como não dá pra brincar, né? Ali é benzer, tomar uns banhos e passar buceta cabaço". ${ }^{1} \mathrm{O}$ relato acima, feito por um pescador e vendedor de peixe no Mercado Municipal do município de Bragança, em meados de 2012, foi uma das primeiras evocações ao Caboclo Ataíde, neste caso, envolvendo a ação desta entidade com as práticas de cura de religiões afro-brasileiras no contexto da região bragantina, nordeste do Pará.

O Caboclo Ataíde é um encantado² presente nas áreas de manguezais, riachos e matas que se manifesta no intuito de seduzir ou castigar pescadores, agricultores, catadores de caranguejo e tantos outros que andam de maneira descuidada por essas paragens. O Caboclo Ataíde é um "encantado enrabador". Através do seu "pau", cujas figurações assumem diversos formatos e disfarces, atinge, fecunda e eventualmente, mata, "esbandalha" ou "escangalha" homens e mulheres que praticam os diversos lugares na região. A narrativa contada pelo pescador ocorreu com seu vizinho, e se não fosse a ação da benzedeira em preparar-lhe cozimento à base de ervas e copaíba, ${ }^{3}$ bem como o massageio da "buceta cabaço" de uma adolescente sobre a área para "amansar" o veneno, a dor não teria cessado e o sofrimento persistiria. 
A aproximação entre o "pau" da entidade e a periculosidade do "ferrão de arraia" fez com que a criatura fosse chamada de "pau de arpão" em outros relatos, numa associação entre a "ferrada" da arraia e o arpão, instrumento predatório utilizado na pesca. O efeito "amansador" do órgão sexual de mulheres e as práticas de benzeduras denotam que a compreensão da presença da entidade na região é diversificada, e dificilmente apreensível na inteireza de uns poucos relatos. A costa do nordeste paraense, com um pouco mais de relevo em direção aos rios e manguezais, é marcada por contatos e representações da entidade que ainda esperam novas pesquisas.

Estudos vinculados ao tema da biodiversidade e populações tradicionais (Perez 2011) interpretam o encantado Ataíde como um protetor local, como reforça Deis Siqueira: "O fato é que a 'aparição' do Ataíde ou de algum outro ser sobre-humano tem como consequência o resguardo do local, ou seja, funciona como descanso e conservação do território por um tempo" (Siqueira 2013:528-529). Entre os catadores de caranguejo, o encantado faz parte do próprio vocabulário cotidiano, confundindo-se com a prática de extração, tal como se atesta no Vocabulário Semi-sistemático da Terminologia do Caranguejo, de Alessandra Vasconcelos Matos: "figura mítica em forma de um homem ou mulher que, segundo a lenda, possui o órgão genital de tamanho bastante avantajado, que ataca os tiradores no mangal para abusar sexualmente dos mesmos, provocando-lhes a morte" (Matos 2001:82-83).

A diversidade de características do Ataíde transparece em outros escritos como um "devorador", ou ainda, "autoantropofágico", conforme os relatos de "O Ataíde autoantropofágico" (Silva; Cardoso \& Pinheiro 2014:10-24), de onde emergem narrativas sobre a criatura se servindo da companhia de pescadores e que, ao mesmo tempo, devora partes do próprio corpo, expressando justamente não apenas o seu aspecto transformacional, mas também a necessidade de interagir, tocar e ser tocado.

Para Camilla da Silva Souza (2013), o encantado Ataíde torna-se um elemento fundamental para perceber as relações homoeróticas dos coletores de caranguejo. Na comunidade de Bacuriteua, local vinculado ao município de Bragança, a autora acompanhou a relação entre o imaginário do encantado na paisagem dos mangues e os relatos orais dos moradores, particularmente, de que forma a dinâmica do imaginário revela a relação desses homens com os seus próprios corpos.

Ainda que preocupada com o recorte estabelecido, Camilla da Silva Souza não se furta de apresentar determinadas aproximações da imagem elaborada/interditada do Ataíde com as dinâmicas das relações de trabalho, religiosidade e das festas locais, como, por exemplo, a singular tematização da entidade no bloco de carnaval em Bragança. O cruzamento entre a aparição 
"fantástica do encantado, denominado de Ataíde" e o "intercurso sexual quando o homem é violado pela criatura habitante do mangue" (Silveira \& Souza 2014) marca o ambiente fronteiriço nos locais de manifestação do encantado.

Na pesquisa de Marcos Vinícius Cunha Oliveira sobre a construção da estrada Bragança-Ajuruteua, PA-458, nordeste paraense, por exemplo, o encantado Ataíde, além de dotado das características mencionadas acima, também se manifesta na beira da estrada, transitando pela PA-458, buscando diálogo com pessoas acampadas e se impondo ao olhar humano na paisagem do asfalto (Oliveira 2015).

A denominação de encantado, ou caboclo, faz de Ataíde parte de um complexo de entidades espalhadas nas paisagens do nordeste paraense, tais como Botos, Matintas, Curupiras, Mães d'água, Jiboias ou Boiunas, seres que aparecem e atingem centenas de pessoas nos locais de suas habitações, estas denominadas de encantaria - locais situados no fundo dos rios, debaixo de pedras, raízes, copas de árvores. ${ }^{4}$ Os encantados se manifestam também quando descem nos terreiros de pajés e de pais e mães de santo, quando dançam, conversam e essencialmente assistem com conselhos e práticas de cura. ${ }^{5}$

Encantaria seria o local de habitação dos encantados, uma comunidade ou cidade composta de entidades de diversas origens, geralmente situadas no fundo de rios, interior de árvores, rochas ou debaixo da terra. Pajés, pais e mães de santo e rezadores capazes de visitar esses locais em transes ou rituais de incorporação também transitam nas encantarias. Entretanto, apesar da percepção inicial de que esses locais são apartados ou dissociados do "lado humano", como um tipo de "dimensão paralela", a pesquisa de campo indica que a encantaria seria um ambiente emoldurado e atravessado justamente pelo aspecto relacional do humano com o não humano.

A existência de uma cidade dos encantados extrapolou o universo de relatos orais, e estudos do historiador Aldrin Figueiredo sinalizam que muitos literatos e "folcloristas" tematizaram os ambientes das encantarias da segunda metade do século XIX até a primeira metade do século XX. A pesquisa de Aldrin Figueiredo também revela como esses locais subaquáticos, seus encantados, seus príncipes e princesas do fundo foram transfigurados dos relatos e incorporações de pajés e praticantes da cura em Belém do Pará para a constituição de certo ideário de modernização e progresso em cidades amazônicas (Figueiredo 2008).

A existência das encantarias acenam sobretudo para os significados atribuídos a elas pelas populações amazônicas, permitindo que tais cosmologias sejam amalgamadas com relatos da percepção cronológica da 
história regional, tal como problematizado na etnografia de Joel Pantoja, quando analisou o paralelo entre as cidades do "ocidente do Marajó" e os "patrimônios do fundo", isto é, as pertenças e os sentidos de comunidades por meio das encantarias (Silva 2019).

Na região bragantina, a definição de encantado aparece com algumas variações, principalmente no que tange à aparência "verdadeira" deste tipo de existente: em alguns casos o encantado é definido como "gente", isto é, um ser humano que ao se encantar tem o poder de se manifestar na "formatura" de aves, plantas, pedras e, principalmente, cobras, jacarés, botos e peixes. Portanto, a faculdade de passar por aparências diversas faz dele um ser que carrega em sua ontologia a vicissitude da alteração (Silva 2014).

Figura 01. Rio Caeté. Local de encantaria: aparição e "desova" do Ataíde. No horizonte, área urbana da cidade de Bragança



Fonte: pesquisa de campo (2016)

A incorporação destes encantados sinaliza uma concepção que possibilita a ontologia de outras espécies se alternarem e se apropriarem no encalço dos humanos, trazendo uma outra perspectiva das experiências xamânicas no contexto amazônico. ${ }^{6}$ Esses relatos se aproximam, hipoteticamente, não apenas das formulações de Viveiros de Castro (1996) e Tânia Stolze Lima (1996), para o caso do perspectivismo indígena, mas também da possibilidade de ligações entre o perspectivismo indígena e as cosmologias de religiões de matrizes afro-brasileiras, notadamente aquelas expressas nos escritos de Valentin Wawzyniak (2003), Márcio Goldman (2005), Edgard Barbosa Neto (2012), Marina Vanzolini Figueiredo (2012) e Jerônimo Silva (2014). 
Embora não busquemos tratar dessa especificidade no escrito, frisamos que o encantado Ataíde acolhe similar potencial predatório.

Ressaltamos que os estudos de Agenor Sarraf sobre a história dos contatos entre africanos e indígenas, em área que o autor denomina de "Amazônia Marajoara", bem como a compreensão de práticas culturais nomeadas de "cosmologias afro-indígenas" são formulações que têm possibilitado situar relações liminares entre cosmologia e história, revisitando a presença africana e indígena na região pela ótica dos estudos de memória e abordagem decolonial (Sarraf-Pacheco 2009). Não se trata, neste texto, de evidenciar ou optar por um "modelo" interpretativo e sim esboçar possibilidades compreensivas acerca das cosmologias do Ataíde.

Nascido de incursões de pesquisa de campo nas vilas de Camutá, Bacuriteua e São Tomé, município de Bragança, litoral do nordeste paraense, o artigo apresenta a forma como o Caboclo Ataíde se manifesta através das narrativas de seus habitantes, passando a compor certo entrelaçamento da faculdade de enrabar suas vítimas e as formas de proteção e cura nos saberes de pajés na região, anovelando-se cosmologicamente a outros viventes da encantaria. Para acompanhar tais desdobramentos daremos ênfase inicialmente ao quadro de aparições do Ataíde e sua relação corporal com as paisagens do mangue.

Figura 02. Mesorregiões do Pará. Banhado pelo Oceano Atlântico, o litoral do nordeste paraense é caracterizado pelo encontro de águas doces e salgadas

$$
\text { MAPA DO PARA' - BRASIL }
$$

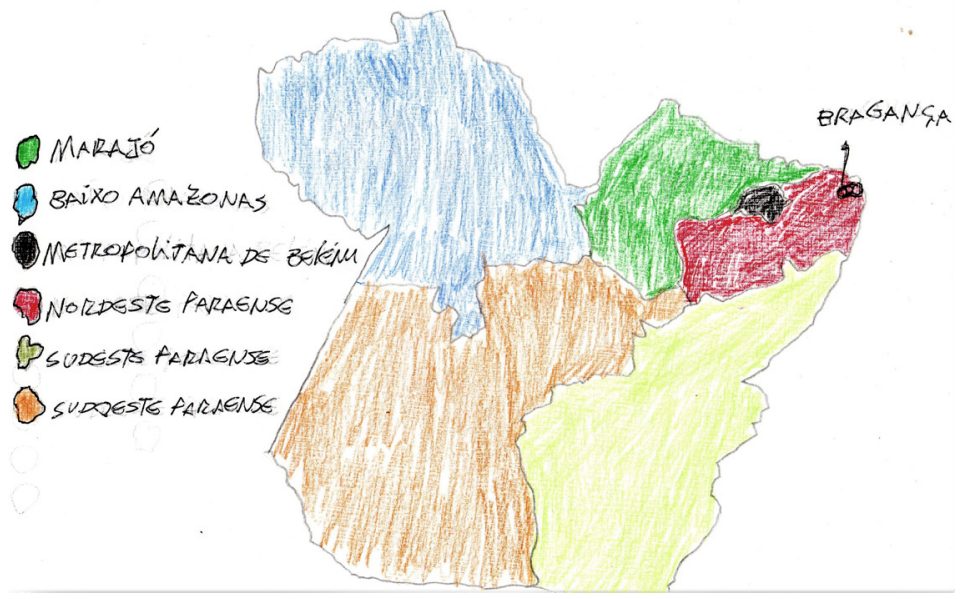

Fonte: rascunhos do campo (2019) 
Figura 03. As incidências de relatos sobre a aparição do Ataíde são encontradas em manguezais e margens de rios. No detalhe, em verde temos áreas de densidade florestal e a Reserva Extrativista Caeté Taperaçu; em vermelho, os locais da pesquisa.

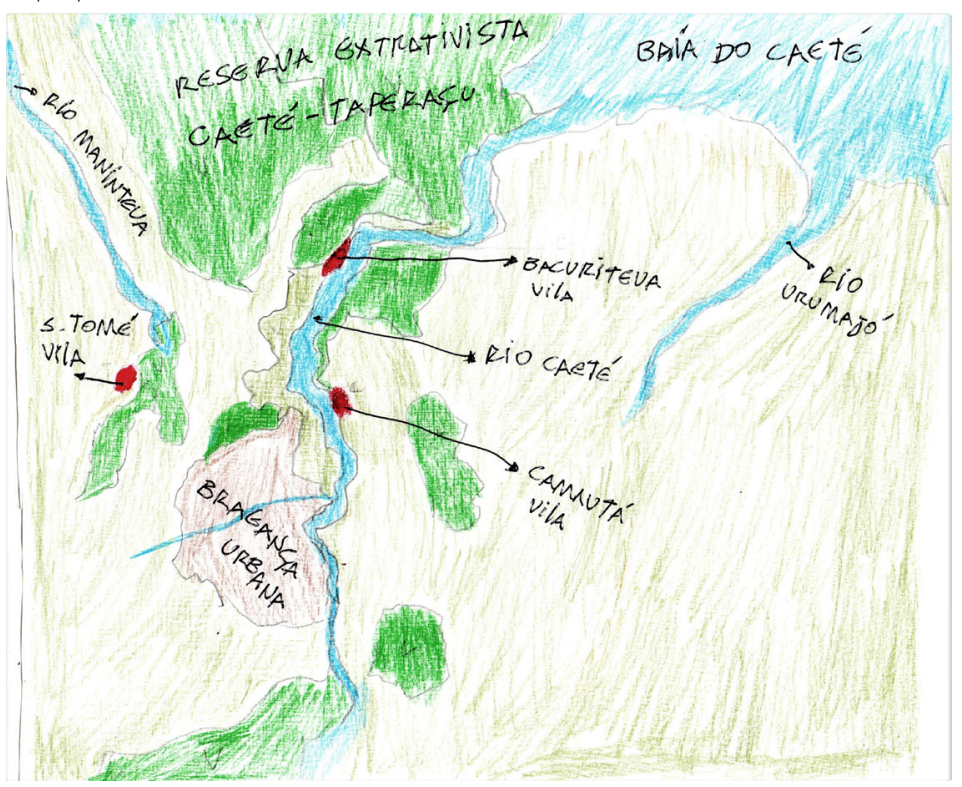

Fonte: rascunhos do campo (2019)

Para compor os elementos apresentados no artigo foram realizadas pesquisas de campo e revisitações da área entre 2016 e 2018, exigindo não apenas a retomada de notas anteriores sobre pesquisa na temática da encantaria (2009-2014), mas também acréscimos de reformulações nos escritos e nos usos de imagens e desenhos. O artigo apresenta inicialmente aspectos gerais da atuação do Caboclo Ataíde nas comunidades, as doenças e as formas de se relacionar com a paisagem. Esta parte é composta de relatos de moradores nas vilas próximas e manguezais, áreas de caça e pesca.

Na segunda parte discutimos como o Pajé Edvaldo interpreta a ação do Caboclo Ataíde no horizonte da cura, das formas de proteção e cuidado junto a si e aos requerentes de auxílio, fazendo emergir as imagens do encantado ora como um protetor de enfermos e desassistidos, ora como um Caboclo temido pela engenhosidade na arte do enrabamento dos incautos, igualmente espraiando tais atributos em pinturas e representações artísticas, metamorfoseando o "Enrabador" em "Enraba-dor".

A "buceta cabaço" da jovem, evocada no início da apresentação, que foi levada pelas senhoras da comunidade para que o seu "cabaço" fosse esfregado e amansasse o sofrimento na perna do pescador atingido pelo "esporão da arraia", e a versão feminina do Ataíde fazem parte justamente do 
último tópico do artigo, neste caso, envolvendo alinhamentos possíveis entre sofrimento físico, prazer sexual e proteção, manifestando-se na entidade que tem um "pau grande como o rabo da arraia com esporão dentro", um falo que independente do lugar atingido faz a pessoa encher as calças ou, conforme afirmações, seria um "pau rasga cu". Ironicamente, tal violência se vê amansada na proposta de cura, disfarce e sedução dada por um oportuno "cabaço"!

\section{Devir-enrabador}

O Caboclo Ataíde é uma entidade que os moradores dizem tratar-se de um ser que sempre atuou na região e que no passado era chamado de "Sarambuí", detendo as mesmas características desde então. Na vila de Camutá, o Ataíde não é um encantado que vive no "fundo dos rios", e sim um habitante do mangue, preferindo esconder-se na mata durante os dias claros para sair na penumbra. O ser encantado prefere dias nublados e noites mais "claras", ou "noites de lua". As narrativas envolvendo a aparição da entidade ocorrem em circunstâncias climáticas de manhãs ou tardes nubladas, assim como dias chuvosos e noites atravessadas por certa visibilidade. ${ }^{7}$

O comerciante Pedro Assis, 63 anos, afirma que, embora não fossem poucos os casos de pessoas que se perdiam nas "jornadas de caça", ficando à mercê de perigos outros, a escuridão entre meia-noite e três da manhã não era temida quando se tratava dos ataques do Ataíde. A predileção por um clima em que o sol e a lua estejam em mediação, interregno, nos informa um traço cosmológico dotado de versatilidade.

No mesmo sentido, a entidade não é associada aos encantados aquáticos, tal como cobras e botos, nem tampouco ao ambiente específico da floresta, a exemplo de curupiras e de determinadas matintas (Villacorta 2000; Fares 1997), sendo na verdade marcada cambialmente pela hibridez fronteiriça entre terra-água, água doce/salgada, condição intersticial do mangue. O ex-pescador e açougueiro Cláudio Pereira, 61 anos, com morada às margens do rio Caeté, evoca algumas experiências.

Assim, primeiro o meu pai já falava desse Ataíde desde muito tempo. Sempre dizia que o Ataíde vivia recoberto da lama do mangue, ela é como se fosse um disfarce em que só reparava mesmo quem via o branco dos olhos dele [...], mas quando isso acontecia, já era tarde, o cabra já tinha sido pego (risos). Ninguém, né?! Por isso diziam também que era um pretão, porque só viam o bicho deitado dormindo nas raízes. Aí quando vinha o rumo de gente na canoa e descia para pegar caranguejo ele ficava só marcando, chegando naqueles mais isolados, e dava no cabra quando já tava assim palmo em cima. 
A lama do mangue é entendida pelo narrador como um disfarce, uma segunda pele que objetiva fazer as pessoas confundirem o corpo da entidade com o ambiente; assim, a capacidade mimética de tornar-se indissociado na paisagem seria uma vantagem salutar, dirimindo as dificuldades de se locomover com um corpo tão avantajado. Se em outros relatos o encantado aparece como um negro corpulento (Souza 2013), neste, o corpo aparece sempre recoberto dos elementos de sua habitação.

Cercado de dois outros moradores e em tom de descontração ouvem-se histórias de pessoas que viram o Ataíde dormindo com o "pau arreado pro lado, igual uma tora de fumo (tabaco)", sugerindo outra artimanha do encantado na oferta de uma aparente "tora de fumo" para ser mascada, apelando para a "fissura do fumo" dos transeuntes, não por acaso um hábito ainda presente em homens e mulheres; ou ainda de coletores de caranguejos que chegavam no mangue e amarravam a corda da canoa no "pau do Ataíde", confundindo-o com troncos de árvores.

O domínio físico visando à penetração poderia ser substituído por surras, dilaceramento do corpo, desaparecimento físico e enlouquecimento, que estavam relacionados com a presença de pessoas em determinadas datas e em horários tidos como impróprios (período da quaresma), ou ainda de pessoas do sexo feminino que estivessem de resguardo ou menstruadas, provocadoras da "zanga" do Ataíde. ${ }^{8}$

A esse respeito Cláudio Pereira afirma que o afogamento de uma adolescente em 1992 foi causado pelo Ataíde e sua "zanga" com o cheiro do sangue menstrual. O ocorrido levou os coletores a andarem durante algum tempo armados com facões e em grupo na área circunscrita: "nesse tempo a gente andava com uns facões amolados esperando pra acertar ele, mas não deu em nada não, porque diz que o bicho se escondia se mudando em toco e monte de mangue, tipo caranguejo". O entendimento sobre a composição do corpo do encantado apresenta a faculdade de mudar de um corpo "envernizado", "todo duro" (troncos e casco de caranguejo), para a "moleza" (monte de lama). 
Figura 04. Encantado Ataíde guarda transmutabilidade com os predicativos corporais do caranguejo

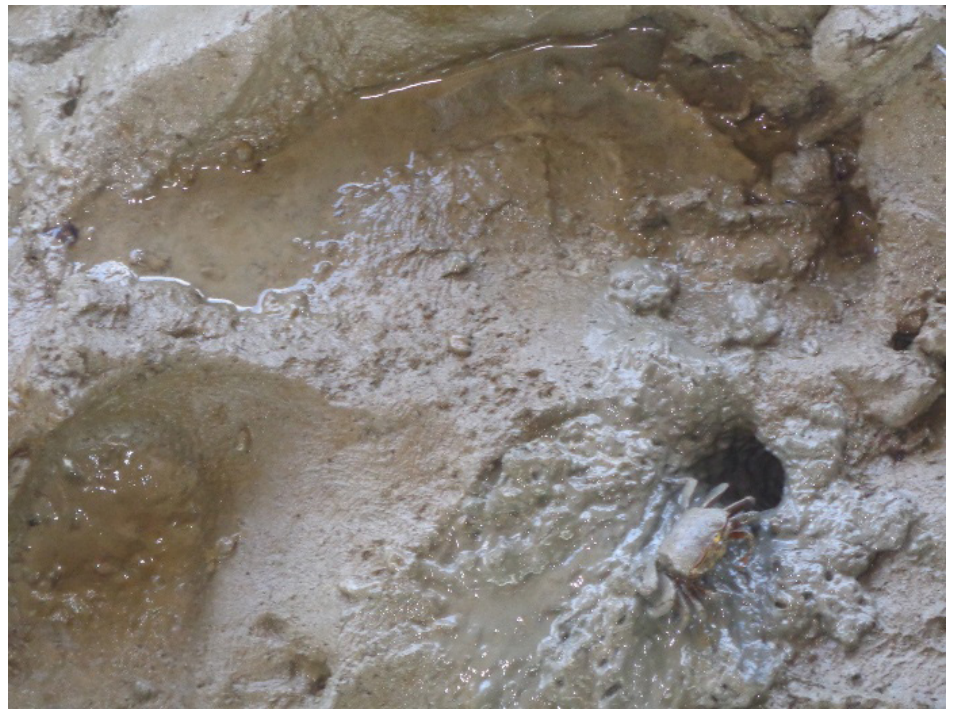

Fonte: registro do autor (2015)

Outrossim, a analogia com os hábitos alimentares do caranguejo e sua forma de sobrevivência guardam associações com uma alimentação oriunda de frutos, folhas, restos de animais e, principalmente, o turu. ${ }^{9}$ Cláudio Pereira relembra que Ataíde é um "comedor de turu", e que no passado esse também era um sinal da presença de Ataíde.

Quando via os tronco arrancado e bem dizer oco, podia sair que ele tinha passado [...] a gente sabia que era ele porque arrancava as casca, era tipo com dentada, parecia que saía mordendo e chupando [...] quando ele tava assim, o medo era maior porque o turu dá sustância e quentura pra dar no couro (risos); parece que o negócio ia todo lá pra baixo [...] aí o negócio era inflamado!

A dita capacidade de estimulante sexual do turu entre a população é bem conhecida, sendo consumido localmente e indicado recorrentemente aos turistas que visitam a região para extrair as propriedades desse molusco. Durante a pesquisa de campo, ainda em Camutá, um grupo de jovens - três rapazes e duas moças - conversavam aleatoriamente e, enquanto aguardavam a chegada de caranguejo e pescado para descarregarem das embarcações, forneciam interpretações a respeito do vínculo do Ataíde com o caranguejo nos manguezais. O ambiente oscilava entre risos e ironias voltadas para o "esquisito" interesse pelo tema. ${ }^{10}$ 
Alex: Esse negócio de Ataíde não é comigo não (risos), isso é coisa, acho, de sacanagem mesmo, invenção, né? Coisa mais de baitola mesmo (risos).

Nonato: Rapaz, professor, né? Lá em casa tem uma conversa que fala que na verdade esse Ataíde era um cabra que vivia em Bragança no passado, e era o comedor geral (risos) de passar manjuba em todo mundo, até que um dia os homem quiseram matar ele e ele se enfurnou no mangue, e daí nunca mais se soube [...] daí virou esse daí (risos), esse papo errado de gente velha, né?

Marina: Pois eu lembrei de uma coisa que vocês se esqueceram, sabia?! Quem lembra do Toninho Sabiá? Lembram, né? Então, ele tá bem velhinho, mas até hoje não recuperou o juízo, ficou surtadinho depois da surra do Ataíde. Foi assim: ele saiu pra caçar e pegar caranguejo sozinho na Quaresma, quando ninguém podia fazer, daí dizem que esse doido aí (Ataíde) deu umas picada nele e ainda surrou com cipó, deixando no chão quase três dias. Depois que encontraram, ele não ficou bom do juízo não, passou a fazer tudo de trás pra frente, e sempre dizendo: "agora vai ser assim" [...] ele num prestou pra mais nada [...] até a mulher deixou ele. Não tô mentindo, ele andava, comia, fazia tudo que nem caranguejo, de trás pra frente!

O aspecto sexual do Ataíde é inicialmente o tema mais valorizado de sua figuração, sempre em tom de chacota, voltada para a construção de preconceitos em relação ao homoerotismo masculino. Entretanto, com o avançar do convívio e quando a conversa adentra experiências religiosas, o tom de seriedade vai lentamente enfraquecendo os sorrisos, fazendo-os "amarelar". O Ataíde aflora nas memórias familiares de Nonato como a expressão da violência exercida por homens que não aceitavam o comportamento de um jovem tido por "comedor geral", interessado em ter relações sexuais com homens e mulheres, por certo, desestabilizando a dita "ordem" ou "normalidade" sexual.

A evocação do caso do Toninho Sabiá nas memórias de Marina traz a faceta de um encantado que, motivado pela desobediência de um caçador descuidado com interdição de caçar no período da Quaresma - momento de recolhimento, resignação religiosa -, fora castigado exemplarmente pela entidade. O enrabamento exercido pelo Caboclo Ataíde teve a função de um corretivo através do arrombamento do corpo. ${ }^{11}$

Semelhante ao "mau-olhado" de determinados encantados e às "flechas" de mães d'água, a "picada" do Ataíde é o seu modo de afetar ontologicamente outros seres, instrumento corporal que transmite certas propriedades do caranguejo ("andar de frente pra trás") no caçador, desorientando-o mentalmente, instituindo a "desordem" quando inserida 
no mundo humano (Silva 2014:70-75; Wawzyniak 2008). Manietado pelo encantado, o caçador perdeu a lucidez psíquica e a potência sexual, posto que "andando sempre pra trás" não conseguiria mais ter relações sexuais.

A ação do Caboclo Ataíde através de um órgão sexual masculino proeminente é o principal vetor do imaginário dos relatos em torno de sua potência. De tão grande o pau era "enrolado no pescoço", um "pau de arpão" ou de "ferrão de arraia" para fisgar, capturar, entrar e "sair rasgando tudo", ou ainda, um "pau" que é um "terceiro pé" a deixar pegadas no mangue, possibilitando correr com destreza, ou ainda um "pau" similar ao "rabo de macaco", agilizando passagem de uma árvore à outra - um corpo construído pelos elementos do entorno (Berque 1998:84-91; Silveira 2005).

Figura 05. Tal como determinados macacos, segundo os relatos, o Ataíde se desloca pelo mangue graças ao "rabo-pica".

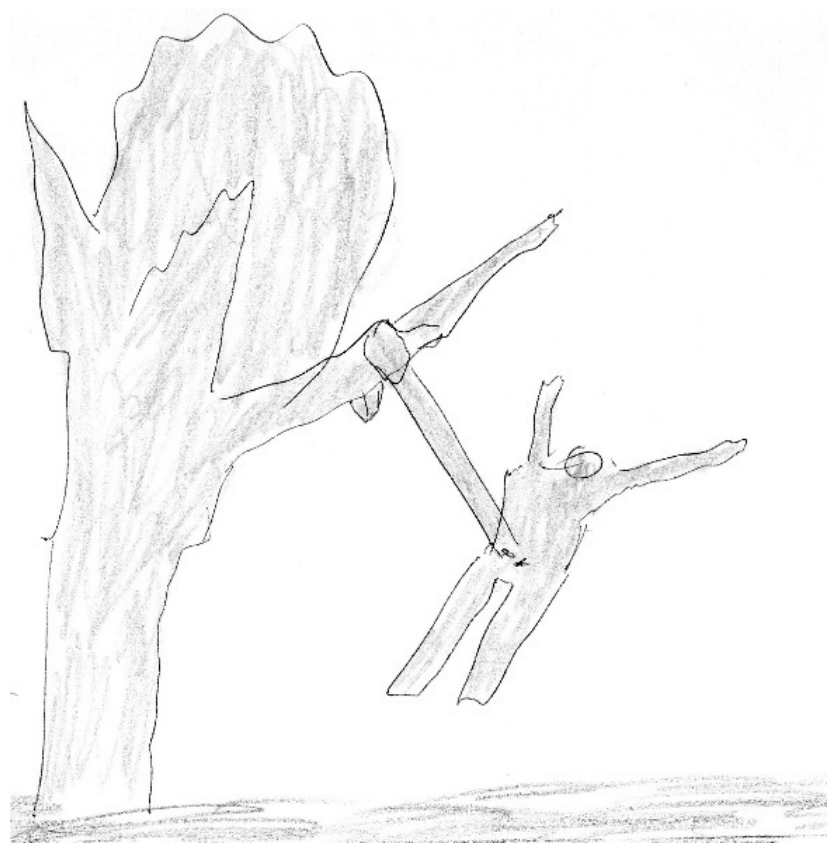

Fonte: rascunhos da pesquisa (2016)

Graças as suas propriedades transformacionais, o encantado Ataíde faz seu corpo se intercalar em "pau", "buceta" e "cu". Pescadores da orla da cidade comunicam a polissemia dos arranjos eversivos da entidade.

José (pescador): Aqui tem os filhos do Ataíde [...] que nesses casos acontecem, ou quando o pescador sai pro rio e o Ataíde se veste igual o marido e pega a mulher [...], ou quando a mulher vai pescar nos mangue e de lá já vem prenha com o sangue forte dele (risos). 
César (pescador): Ele é um bicho com os dois juntos, com buceta e pica, dizem [...] vem como mulher loura com xiri que recende de longe [...] com uns beição (do xiri) assim grande, uma chapa! Não tem esse que se segure, tá? (risos) E quando tá sendo comido aparece um rabo, que, que, na verdade, é a pica, que passa devagarzinho por trás e sai metendo que quando viu... Já foi é muito (risos), daí quando aparece mulher, assim do nada, o lance é pegar por trás e depois pela frente pra se assegurar e tirar o fo-fo do perigo.

Arlindo (pescador): Diz que tem uns e outro aqui que come viado, que se fodem na mão dele [...] quando saem na calada pra comer a molecada gay aí e tão lá enfiando de boa (risos), o cu faz é torar ou macerar os bago, fica um desmantelo só (risos), mas ficam caladinho pra não ser encarnado.

Figura 06. Ataíde e o terceiro pé. Pau-caminhador? Pé-enrabador?



Fonte: rascunhos da pesquisa (2016)

O Ataíde ou assume a forma do marido para manter relações com as mulheres, ou as seduz no mangue; para o primeiro caso, a mulher só descobre que o suposto corpo do marido é o disfarce do encantado ao se iniciar a penetração com o avantajado órgão sexual, ali, depois de estar "fincado", além de não conseguir reagir, apenas emite um grito em que se misturam dor e prazer. Os gritos de vozes femininas no mangue sinalizam, nesse sentido, duas interpretações básicas dos narradores: mulheres desacompanhadas sendo "curradas" pela entidade, ou a própria entidade imitando gritos ou assovios femininos para atrair os homens à emboscada. 
Figura 07. Pau de Arpão. Ataíde caçando coletores de caranguejo

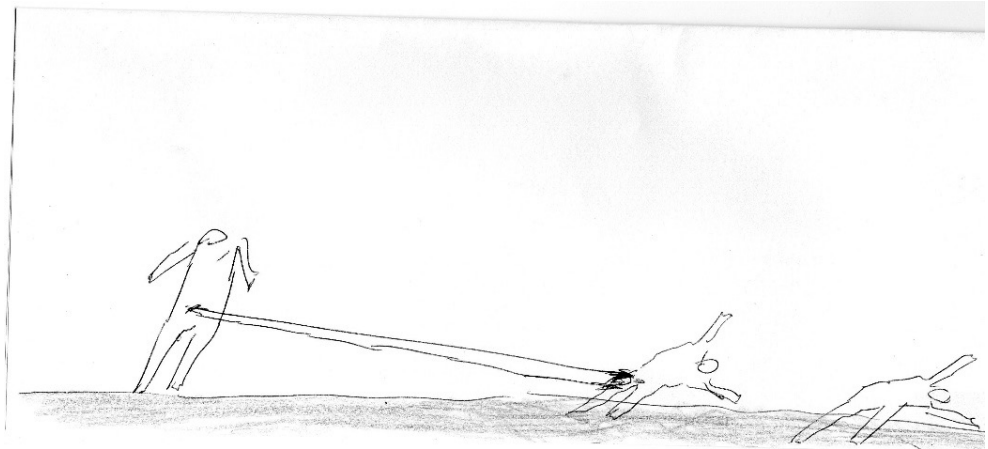

Fonte: Rascunhos da pesquisa (2016)

Uma mulher pedindo ajuda, gemendo ou assoviando, pode ser o arabesco do Caboclo. Uma loura alta, de cabelos longos e corpulenta, detentora de quadris largos, pernas grossas e um "xiri" que seduz pela grandeza dos "beiços", associado a um cheiro irresistível que se espalha deixando qualquer homem de "pau teso", é a versão feminina do Ataíde, apresentada acima por César. Enquanto o morador local se dedica inteiramente à penetração sexual, paralelamente emerge do "cu acochado" da jovem sedutora uma "pica", ou ainda, um rabo que "na verdade é a pica", deslizando e enrabando a "vítima": esse enrabamento não é marcado pelo "escangalho" do corpo. A oferta do "xiri" reveste-se de uma "isca" para o imprudente, deslocando a atenção e anestesiando o "cu" ante as primeiras penetrações, para, em seguida, cair em si no instante do recebimento da penetração total, quando não há mais nada a evitar.

Descobrir a artimanha do encantado só é possível enrabando o enrabador... devir-enrabador, ou seja, resistindo à beleza e ao encanto do "xiri" e passando imediatamente para o "cu", isto é, deixando a "isca" e desmontando a armadilha, desmascarando o captor, desarmando-o, pelo "cu", casa e disfarce cosmológico do "rabo-pica". Aqui, "comer o cu" é fundamental para que este não se transforme em "pica". ${ }^{12}$ 
Figura 08. Nesta perspectiva, o Ataíde, em sua "formatura de mulher", atrai os homens com um "xiri" irresistível, para, em seguida, dar o bote na presa

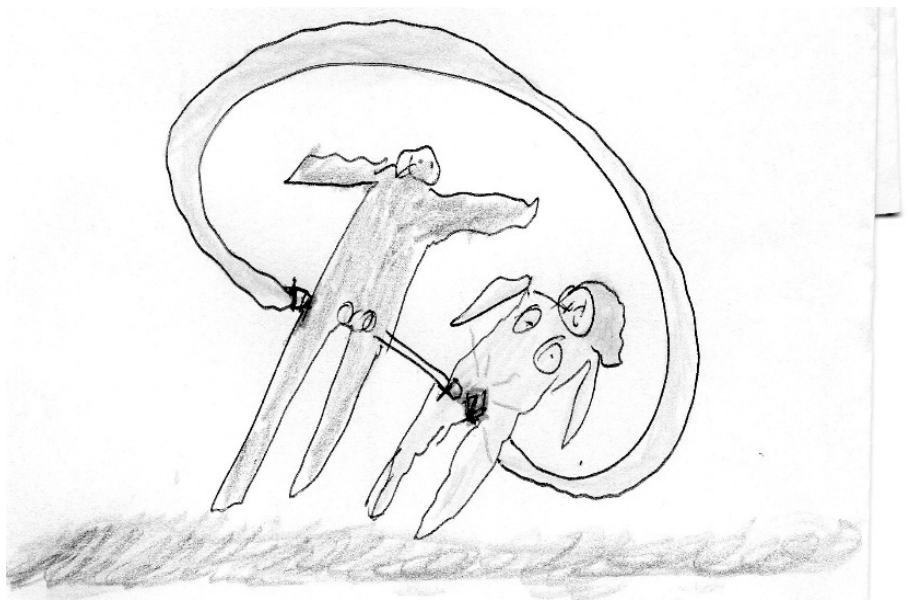

Fonte: rascunhos da pesquisa (2016)

O cuidado manifestado no conselho de César não parece encontrar previsibilidade nos atos do encantado narrados por Arlindo, o pescador. Uma digressão das notas de campo faz-se necessária. Arlindo compôs o seu relato enquanto remendava redes de pesca e organizava os anzóis na Orla, alternando descrições de sua atividade e acalentando a "curiosidade do professor", na maioria dos casos reclamando dos jovens pescadores que não sabiam pescar, deixando "a isca ser levada" ou "puindo as linhas". Os indícios que permitiram aproximar a relação entre pescar e enrabar nasceram desses registros.

Se a ação do encantado Ataíde através da "formatura" de mulher se deu por um processo de sedução ocorrido ocasionalmente no mangue, no último caso a situação se inverte, na medida em que se tem a saída noturna, sob a penumbra, de homens em busca de relações com jovens da localidade. O encantado se disfarça de um jovem rapaz, se mistura entre os pretendentes e frequenta a Praça, o Coreto e a Orla, aparecendo aqui e acolá, arrancando o enamorado do seu espaço familiar para o isolamento necessário, semelhante ao experiente pescador que diante de um peixe forte demais para a "linha do anzol", temendo perdê-lo, libera e puxa a linha estrategicamente, arrastando-o para uma área mais rasa, onde, distante do cardume, segue exaurindo sua resistência até o desfecho, desvelando a tragédia de toda caça: o destino de ser "pego" pelo desejo de "comer". 
Figura 09. Segundo alguns relatos, a entidade tinha aspecto corcunda graças ao peso do pau enrolado no pescoço

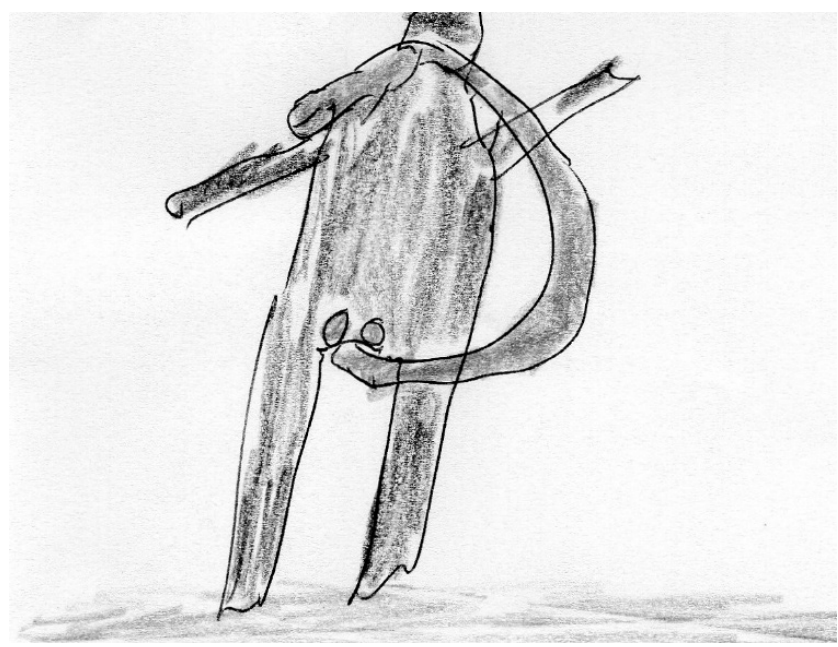

Fonte: rascunhos de campo (2016)

"Torar", "mastigar" ou "macerar" (chupar) até os "bagos" (colhões) daqueles que mordem a isca denotam a habilidade de Ataíde em transmutar a boca, outrora capaz de arrancar cascas de árvores e chupar turu, para o "cu-mastigador". Esta faculdade transformacional que mescla e alterna "pau", "cu" e "xiri", embora possa ser tema de uma reflexão particular sobre gênero e corpo, num outro plano é mobilizada para ser pensada a partir da ideia de punição e sedução, constituindo certa forma de contato entre pessoas e encantados, na medida em que os castigos são exemplos de uma legislação cósmica que costura corpos e mundos cosmologicamente distintos (Latour 1994; Silva 2018). 
Figura 10. Segundo os moradores, "estar de bobeira pro Ataíde" é justamente manter-se desatento em áreas do mangue no horário de meio-dia, a exemplo deste anônimo pescador

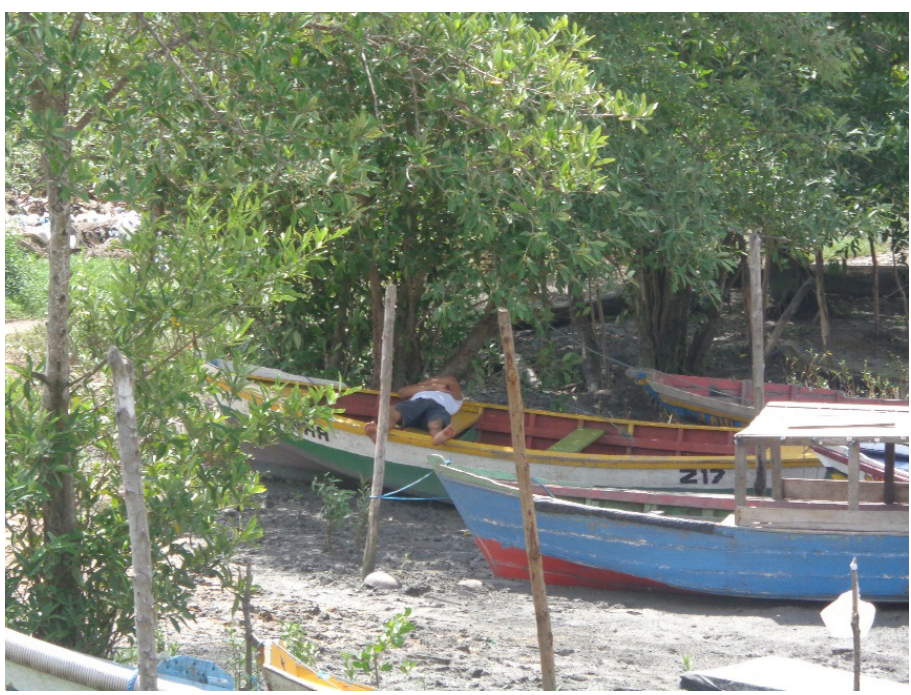

Fonte: registro do autor (2015)

Ainda que a arte da sedução se configure numa cadeia de eventos punitivos, de forma alguma a eles se limita. A ação do encantado em tentar desorientar pessoas nas paisagens praticadas, os assovios, as "miragens" (ilusões visuais), a visita sexual ao leito das mulheres casadas no período de coleta do caranguejo e a sedução dos "boys de bobeira" na Orla noite adentro nos informam justamente de um sistema predatório dado nessa cosmologia que não se mantém apenas enquanto esforço de sobrevivência alimentar, e sim como ato de vingança (originado na "bobeira", "marcação de toca"). É pertinente considerar que a relação vingança-prazer nem sempre é enfatizada nos registros locais, em alguns casos, talvez por "pudor", a ação de Ataíde se manifesta mais como um ato de vingança gerado pelo descuido de pessoas com o meio ambiente (Oliveira, Reis \& Santos 2018).

Outrossim, a ênfase na relação vingança-prazer está intimamente relacionada com o poder do encantamento e a tessitura do feitiço, elemento central na cosmologia do encantado. Nessas trilhas, além de desenhos de seu corpo, a imagem de Ataíde também ganha a forma de bonecos de pano confeccionados para venda em feiras comerciais de Bragança e Belém. Ainda que tenhamos na comercialização dos bonecos certo apelo que destoa dos objetivos deste escrito, há outros dignos de nota. A aquisição do boneco do Ataíde por parte de alguns moradores de Bragança seria compreendida como uma forma de absorver propriedades direcionadas para "proteção" contra "energias negativas", ou ainda como um vetor do "aumento da sedução". 
Manoel Almeida, 47 anos, proprietário de um discreto bar em Bragança, assevera que a aquisição do boneco do Ataíde é parte de uma estratégia de proteção, um tipo de "amuleto protetor" que cria uma "barreira" contra as pessoas mal-intencionadas.

Aqui eu deixo ele pendurado no banheiro, em cima do vaso [sanitário], porque o banheiro no bar é o lugar que a pessoa vai deixar tudo que não presta, sabe, é o lugar onde as pessoas põe pra fora pelo buraco o que não serve [...] ele é tipo uma coisa engraçada que as pessoas ficam rindo, daí ninguém percebe a proteção, sabe? Se fosse uma outra imagem podia ser que os clientes não gostassem [...] (Manoel Almeida).

O encantado Ataíde exerce no bar de Manoel Almeida o papel de força de retenção de "tudo que é ruim" que um corpo "sujo" detém. O que isso significa? Manoel Almeida explica que o Ataíde é um encantado que tem a função de "limpar o mangue" da sujeira que as pessoas deixam no local, que pode ser tanto a poluição da emissão de dejetos quanto, principalmente, a punição de um "espírito sujo".

A penetração no orifício de homens e mulheres no mangue adquire no bar do narrador o objetivo de "tapar a sujeira", isto é, de enlaçar as propriedades cosmológicas tidas como negativas presentes em seus clientes. Da mesma forma, o boneco do Ataíde na residência denota uma proteção contra possíveis "pretendentes" que queiram ter relações sexuais com esposa ou filhas, fazendo "murchar" o pau do "pé de pano" (alusão feita ao homem que se aproxima discretamente para ter relações sexuais com mulheres casadas), evitando a vergonha do "chifre" ou a gravidez "indesejada" das filhas.

As imagens abaixo, capturadas na página do Facebook da empresa Saci: Oficina Criativa - @sacioficinacriativa é um exemplo significativo de iniciativas voltadas para a comercialização, embora não seja a única, de bonecos e representações de inúmeras entidades da encantaria amazônica que possibilitam uma leitura de seus usos que dialogam com a função, conforme visto, de proteger, como uma "capa" a encobrir o corpo contra malefícios e, ao mesmo tempo, em mediação com os bonecos da encantaria, se apropriam de seus predicativos cosmológicos. 
Figura 11. Boneco do Ataíde: imagens comercializadas por empresas virtuais e artistas paraenses eventualmente são utilizadas como "amuleto" ou formas de evitação de "homens afoitos"

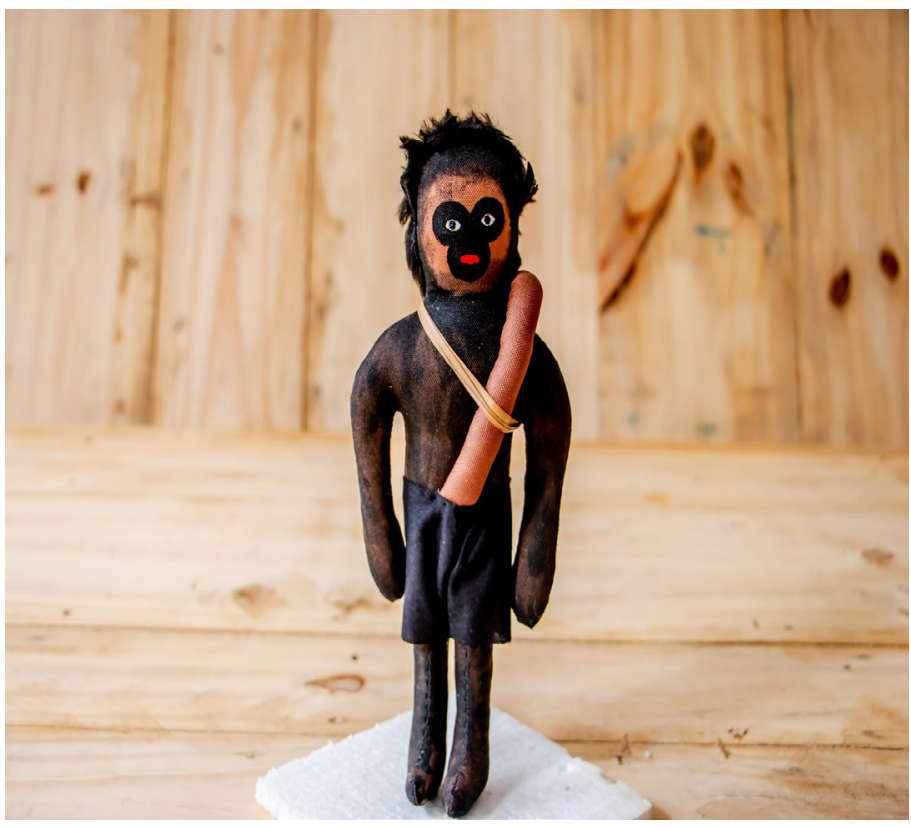

Fonte: https://www.facebook.com/sacioficinacriativa/ (2020)

Figura 12. Boneco do Ataíde. A aquisição de bonecos do Ataíde com o "pau amarrado" teria o objetivo básico de manter uma proteção ao portador e sua família, mas o Ataíde com o "pau solto", conforme a imagem abaixo, denota a potencialização de suas propriedades sexuais



Fonte: https://www.facebook.com/sacioficinacriativa/ (2020) 
No que concerne às atribuições de entidades na interface das formas de compra e venda, e seus sentidos na mobilização da vingança e do prazer no mundo amazônico, percebemos, em diálogo com a etnografia de Bruno Domingues sobre as ditas relações "cosmoeróticas" na cidade de Abaetetuba, estado do Pará, que o manuseio decorativo praticado no cotidiano de grandes cidades não se coaduna com o manejo engendrado em locais no interior da Amazônia. Isto quer dizer que a pesquisa de campo que envolveu a circulação de objetos nas "tendas" de artefatos de religiões afro-brasileiras e a sua mobilização afetiva por pessoas que buscavam saúde, prazer, vingança no circuito de demandas eróticas permitiram compreender a dinâmica de códigos morais, bem como a redistribuição cosmológica entre pessoas, "artefatos" e entidades da encantaria, entabulando redes eróticas e encantados, por fim, questionando o problemático discurso de que cidades e locais no interior do estado são conservadores e repressivos (Domingues 2019:54-67).

A interlocução entre punir e seduzir ou vice-versa se apresenta com outras nuances quando observamos o assento do Ataíde nos terreiros de religiões afro-brasileiras, particularmente se atentarmos para a relação da entidade com pajés durante a incorporação e nos rituais de cura. É o que será analisado no âmbito do terreiro do Pajé Edvaldo, Vila de São Tomé, Bragança.

\section{A peleja entre Jiboião e Ataíde}

A Vila de S. Tomé constitui-se numa localidade situada a aproximadamente $4 \mathrm{~km}$ da cidade, interligada por fazendas de médio porte e ramais. A residência do pajé fica quase no centro das casas. Trata-se de uma habitação de alvenaria, larga e bastante alta, cercada de arame farpado e belos portões pintados à base de cal; ao redor, o quintal apresenta criação diversificada de animais domésticos.

A relação com o Pajé Edvaldo, 28 anos, foi estabelecida em pesquisa de campo realizada entre os meses de maio e outubro de 2013. Essas inserções no campo de pesquisa foram caracterizadas pela observação do cotidiano de vizinhos, requerentes e parentes, associada à manutenção de um diário de campo e à participação em algumas reuniões no "quarto" onde eram realizados os ritos de cura. Edvaldo nasceu na Vila S. Tomé, e seus pais também são originários da cidade de Bragança. Segue o relato sobre os anos de iniciação, envolvendo Edvaldo e as entidades. 
Até os 20 anos, eles (caboclos) falaram pra mamãe que, se eu não aceitasse, eles iam me levar, não era pro mal, mas pra ajudar os pobres que tinham coisa ruim. Desde a idade de 7 anos eu desmaiava e ficava praticamente nu, e ninguém sabia o que era. Então, mamãe me levou pra me tratar com uma mulher que era pajé lá, e ela disse: "Oh, oh que abaixa nele é muito forte! Eu não posso mais do que ele, mais do que ele só Deus". [O meu trabalho] é oração e o fumo do guia com as consultas lá atrás, só que eu não cobro nada pela consulta. Aí eu comecei a trabalhar e a primeira pessoa que fiz um trabalho foi pro meu irmão, que estava quase paralítico e depois ficou todo bom. Foi assim, a mulher pajé que me arrumou pros guia disse pra eu esperar o tempo do meu corpo ficar forte, senão eu podia até morrer. Quando foi um dia, os guia baixaram em mim e eles pediram só umas roupa dele, e depois da reza do guia, ele ficou curado. Daí em diante veio muita gente atrás de mim de todo esse povoado. Mas esse dom que Deus me deu foi diferente dos que dizem que tem por aí. Os meus parentes mais antigo diz que tinham a mesma coisa [...] todos esses lugares eu sou conhecido como pajé mesmo, mesmo de todos (outros) lugares, Bela Vista, Capanema, Gurupi, Castanhal, Belém.

As memórias de antepassados capazes de incorporar e rezar apresentam elementos esclarecedores sobre o "dom" transmitido por descendência, elementos estes ligados à experiência familiar, mas não minimizam a necessidade de a criança ser conduzida a pajés, benzedores ou mães de santo para alcançar a cura de suas aflições, estabelecendo uma relação com as entidades por meio de ritos de iniciação que caracterizam a formação do pajé, que poderia geralmente ser adquirida após o nascimento, ou ainda ser dada "de nascença" (Maués 1995; Trindade 2007).

Ainda que os estudos de encantaria sejam uníssonos sobre a tese de que é o dom que instaura a comunicação com os encantados, enfatizamos um aspecto decisivo e pouco abordado para alcançar o lugar do Caboclo Ataíde nos trabalhos de cura de Edvaldo, que são as categorias nativas de "corda", "correias" e "viração". Se possuir o dom significa ter a sensibilidade ou a abertura do corpo para ver e ser visto pelos encantados, o dom só será eficaz se o detentor desenvolver expertise em compreender quais são as entidades que poderá acessar ou incorporar. Nesse sentido, caberá ao iniciado aprender que todo esse complexo está fundamentado na noção de "correias" ou "cordas", termos que designam como um grupo de entidades se conecta por afinidade e são coaguladas no corpo do portador. Assim, para cada grupo presente em uma "correia" ou "corda" temos uma "chefia" ou "guia" principal, que direciona as ações dos demais. 
A etnografia de Silva (2014) perseguiu as diferentes maneiras com que "cordas" ou "correias" foram repassadas entre corpos de "mestres" e "iniciantes" no nordeste paraense, descrevendo uma dinâmica baseada na transmissão, na passagem dos arranjos cosmológicos nos corpos entre as entidades e os "aparelhos". ${ }^{13}$ A adequação entre "cordas" ou "correias" aciona os encantados e exige a capacidade do iniciado de realizar a "viração". ${ }^{14} \mathrm{~A}$ iniciação do Pajé Edvaldo a partir da relação entre as "cordas" ou "correias", bem como a destreza de fazer a "viração" de grupos ou famílias de entidades ajudam a compreender o lugar do Caboclo Ataíde nessa configuração cosmológica associada aos processos de cura no terreiro do narrador. ${ }^{15}$

As principais entidades eram o Caboclo Sete Correnteza, Preto Velho da Casa de Salomé, Boiadeiro Corre Campo, Caboclo Pena Azul e Caboclo Zé Raimundo Vira Mundo, este último apresentado como o "dono chefe da cabeça do cavalo" (o corpo que recebe as entidades) e "forte para fazer a viração" no controle de outros encantados, sendo eficiente em "desembaralhar" a vida do iniciado. Dentre algumas situações presenciadas em campo, daremos relevo a um caso de "doença" ou "feitiço" envolvendo a "peleja" entre os encantados Caboclo Jiboião e Caboclo Ataíde.

Entre junho e julho de 2013, Edvaldo recebeu visita de duas mulheres - mãe e filha - Antônia, 62 anos, viúva; Jéssica, 21 anos, moradoras da vila de Bacuriteua. Na ocasião, Jéssica reclamou de insônia, dores no corpo e fraqueza física, atribuindo inicialmente os sintomas à anemia; entretanto, após a negativa dos exames médicos, passou a acreditar gradativamente na origem "espiritual" ou "feitiço" dos incômodos que sentiu. Dona Antônia, sua genitora, católica fervorosa, insistiu desde as primeiras visitas que se tratava de "feitiço" lançado por algumas mulheres invejosas da comunidade: a beleza da filha atraía, mesmo "sem querer", o olhar de maridos e noivos.

As duas primeiras sessões de cura eram caracterizadas pelo aconselhamento de ordem alimentar (baseada em determinados tipos de peixe, suco de abacaxi com hortelã e galinha caipira sem sal) e de hábitos cotidianos (evitar ficar na rua depois das 20 horas, sábados e domingos). Posteriormente, prescreveu chás, insumo com raízes e sementes diversas.

A partir da terceira sessão Jéssica passou a ser requisitada para receber rezas e conversar com os caboclos no aparelho de Edvaldo. Em um desses momentos, tomada pelo encantado Caboclo Jiboião, Jéssica jogou-se no chão de tal forma que os ajudantes do pajé tiveram dificuldade para contê-la: seu corpo deslizava pelas mãos, transpirando líquido oleoso e exalando odor de peixe; diziam algumas testemunhas que se tratava de "pitiú" (cheiro) de cobra. Retirar Caboclo Jiboião da jovem tornou-se o objetivo da sessão: cantar hinos de despedida para a entidade - "adeus seu Jiboião, vai em paz que a 
paz é contigo/ vai pro limo que o prumo é lindo", e cobrir o rosto da entidade com pano branco para "amansá-la" foram algumas ações responsáveis pelo afastamento do encantado.

Associado a um encantado de cobra vivente nas águas e responsável por afogamentos, virada de canoas e capaz de penetrar em corpos desprotegidos, Jiboião se configura nos relatos de Edvaldo como "pescador (que) era escravo no passado [...] que foi encantado e vinha sumir com as pessoas que ficavam no pecado na beira do rio", e atualmente, quando incorpora, se caracteriza pelo avermelhado na pele e nos olhos do possuído, com o ardil de fazê-lo deslizar em areais imitando o ofídio.

Figura 13. "Formatura" do Caboclo Jiboião. Anotações de pesquisa inspirada em narrativas de moradores da comunidade de S. Tomé

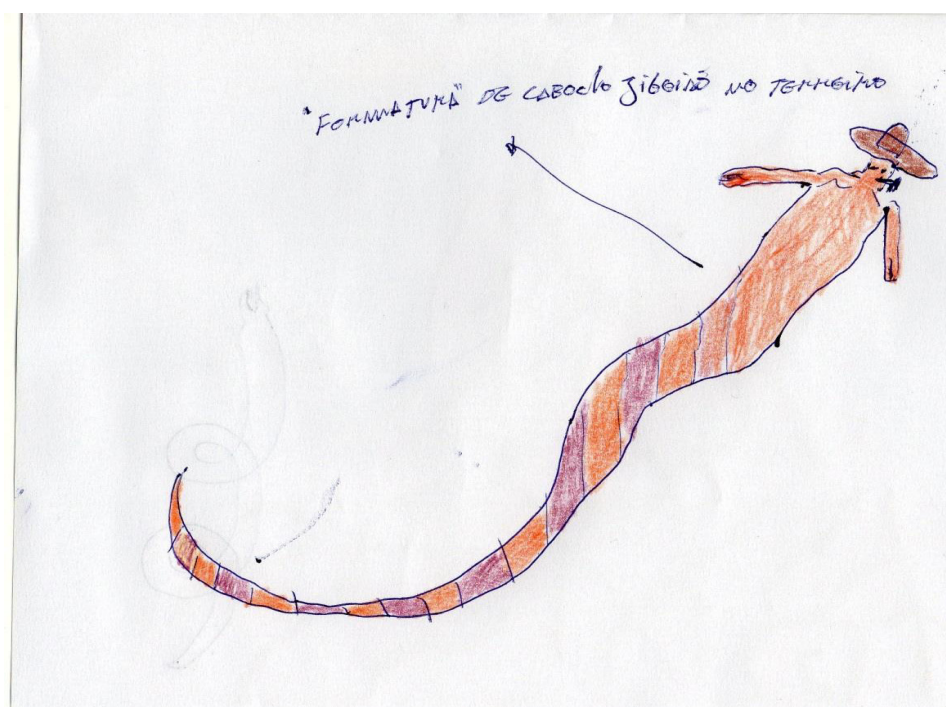

Fonte: rascunhos da pesquisa (2014)

Informado pelo Guia da Corda do Pajé, Caboclo Zé Raimundo Vira Mundo, tivemos ciência de que o vínculo de Jiboião com a requerente foi estabelecido pelo lançamento de um "feitiço": "isso foi feito com raspagem de couro de cobra [...] te deram pra beber nessas festas aí [...] o teu corpo se misturou com cheiro de cobra só pra chamar ele, né? Já viu [...] ele ia te sugar todinha".

No enredo, mulheres ameaçadas pela beleza de Jéssica acionaram, por intermédio do feitiço, a remoção do fascínio ou "faceirice" sobre os homens da localidade para o olhar da entidade, fazendo com que Jéssica tivesse sua beleza "sugada" pelo Caboclo Jiboião, deste modo, a beleza, pela prerrogativa do "feitiço", passara a ser a causa da humilhação sobre 
a portadora da beleza. Para se livrar do "encosto"16 foi recomendado que fizesse três sessões de cura com incenso, seguidas de asseio com água morna imersa em chá de camomila, para "limpar" e "combater o pitiú" (odor) deixado pelo couro de cobra.

Realçamos que a mobilização do encantado sobre o corpo da jovem é parte de uma elaboração de vingança que tem em seu conteúdo estrutural um rito de humilhação: o deslocamento e exposição pública de Jéssica e sua mãe da Vila de Bacuriteua para a Vila São Tomé. O definhamento de pernas e quadris ante os olhos de familiares e conhecidos tornou-se signo punitivo para a moça que, supostamente, ousou desestabilizar a hierarquia das relações afetivas.

A estruturação dos exercícios de humilhação, segundo Díaz-Benítez, é modelada na percepção das pessoas pelo prisma das hierarquias estabelecidas, podendo direcionar práticas vingativas que oscilam entre "o desejo pela aniquilação do outro em sua versão mais funesta, ou pode nos levar a desejar a permanência desse outro sempre e quando se mantenha em seu lugar" (Díaz-Benitez 2019:69). Embora reconhecendo a distância temática das reflexões da autora, pensamos na diligência dos atos punitivos envolvendo a profunda humilhação social arregimentada por aqueles que recorrem aos encantados para execrar os "antipáticos" ou indesejáveis em determinado grupo.

O vilipêndio do outro, entendido como a ostentação particular de um troféu, que deve ser mantido à mostra para satisfação de seus agenciadores e do escrutínio coletivo, talvez converse menos com a dita "maldade humana" e mais com as práticas cotidianas de organização de mundo, deixando ver em nossas ações aparentemente "bondosas" não poucas formas grotescas de rebaixamentos (Díaz-Benitez 2019).

Tais exercícios, para a urdidura desta etnografia, engendram a busca do prazer, a sedução, a vingança e a humilhação como processos enlaçados na intrincada teia cosmológica que envolve as entidades, o pajé Edvaldo e Jéssica, vertendo a luta pela cura de Jéssica em expressão de litígio das entidades, quer na ocupação dos territórios pelos encantados na cena da cura, quer na recomposição da "faceirice" de Jéssica, colocando em interlocução vingança e cura no mesmo território.

A outra recomendação do Caboclo Zé Raimundo Vira Mundo seria a de recolher e levar as toalhas e os objetos de asseio para que os jogasse no outro lado do rio, finalizando a orientação com a frase: "Manda pro Ataíde que ele resolve pra lá". 
O Ataíde é um encantado que não desce assim não, é um caboclo brabo, o pessoal fala a sacanagem dele (risos), mas num vê que tudo nesse mundo tem serventia. Ele é um caboclo bruto, sim, mas ele já fez cura, e às vezes a única coisa que pode com um bruto é bruto e meio, né?! Ele bate é de frente com esses outros [Jiboião] e não enverga não. Vou lhe dizer, se fosse outro ia já mandar a moça [Jéssica] mandar o feitiço de volta pra quem mandou, era só mandar o fedor da cobra de volta, aí o bicho [Jiboião] ia voltar era com zanga dobrada, né? Porque foi enganado [...] mas veja que mandei só jogar naquelas banda do outro [Ataíde], certo? Porque o Ataíde também faz cura, só não desce em terreiro, por isso que digo que lá eles se engancho [brigam].

Assim, o Caboclo Zé Raimundo Vira Mundo, Guia da Corda de Edvaldo, seria capaz de entremear-se nas "cordas" de "outros tipos de caboclo", desatando ou "desligando" a doença ou "flecha". ${ }^{17}$ A participação deste Guia seria importante porque na relação de mestres e iniciantes da encantaria existe o perigo de terem suas "cordas" ou "dons" enfraquecidos, produzindo o cuidado constante de estar "cabreiro", um tipo de rivalidade pautada em constante vigilância e situação liminar da troca de "feitiços" (Lima 1996; Wawzyniak 2008).

Longe de ser entendido apenas como um existente "malinador", pode ser acionado tanto como agente da cura quanto força protetora, como podemos observar no "banho de amansamento". Aparentemente, o isolamento definitivo do feitiço lançado sobre a filha de Antônia precisaria de um efeito neutralizador, fato este possível apenas com uma entidade "braba e meia". 18

Figura 14. Caboclo Zé Raimundo Vira Mundo (ao centro). Considerado em alguns terreiros como capaz de passar e doutrinar pelas "cordas".

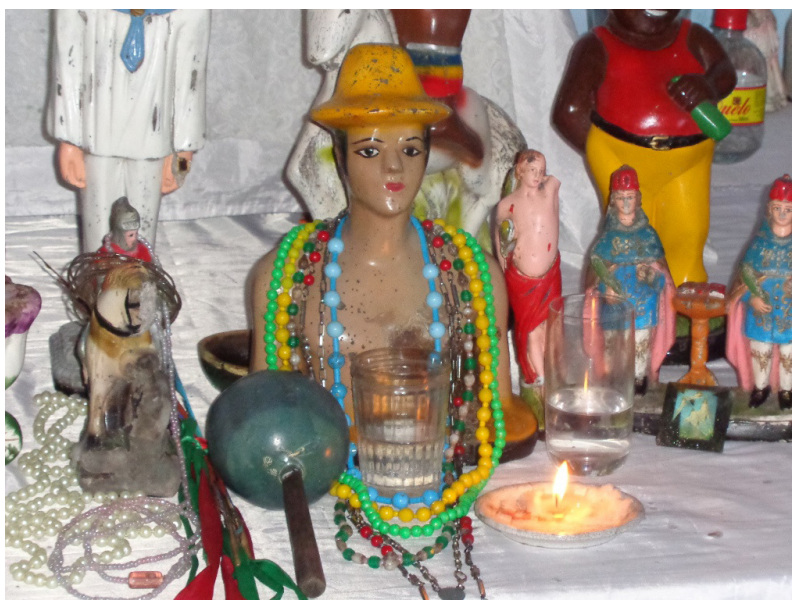

Fonte: foto da pesquisa. Jerônimo Silva (2014) 
Neste sentido, o acesso à cosmologia de seres encantados pela incorporação no terreiro e suas manifestações são passíveis de adequação, na dependência da capacidade dos envolvidos de captarem o momento da "viração", isto é, da transmutabilidade. Esta perspectiva se assemelha aos usos das partes do boto analisado na pesquisa de Bruno Domingues, na medida em que o manuseio do sexo do boto, dependendo da especificidade do contexto, resultaria nas alterações do corpo de seu portador:

Dizer que a vagina da bota é idêntica à da mulher é primeiro admitir que a bota atingiu certo grau de humanidade, é olhar para o animal não mais como um simples boto, mas ser capaz de perceber o verdadeiro ser por trás dele. Utilizar termos como "buceta da bota", "xiri da bota" acaba por assim auferir caracteres antropomórficos ao animal, pois, já mencionados são gerados e difundidos a partir das socialidades (Domingues 2019:74).

O lugar de Ataíde outrora caracterizado pela dita violação sexual no mangue se torna o portador da proteção, obstaculizando as volições do Caboclo Jiboião, operando um conjunto de ligaduras que, além de se expandir para esferas terapêuticas da vida, transborda para contextos sociais mais amplos da vida pública em Bragança, reconfigurando situações de sofrimento. Enrabador. Enraba-dor!

No dia 13 de dezembro de 2018, os moradores da cidade de Bragança foram surpreendidos com a presença do Caboclo Ataíde na Praça Edwaldo de Souza Martins. Tratava-se de uma pintura em grande escala feita pelo artista Moacir de Pinheiro Cardoso Filho. O portal de notícias G1 - Rede Globo, ainda no mesmo dia, publicou uma matéria, com o título "Desenho de lenda amazônica com pênis gigante causa polêmica no interior do Pará", buscou retratar o ocorrido apresentando a imagem como típica da "lenda do Ataíde". ${ }^{19}$ 
Figura 15. Pintura do Ataíde na Praça Edwaldo de Souza Martins, município de Bragança. No detalhe, Ataíde segura um caranguejo em uma das mãos. Segundo o autor, o falo representaria um turu.

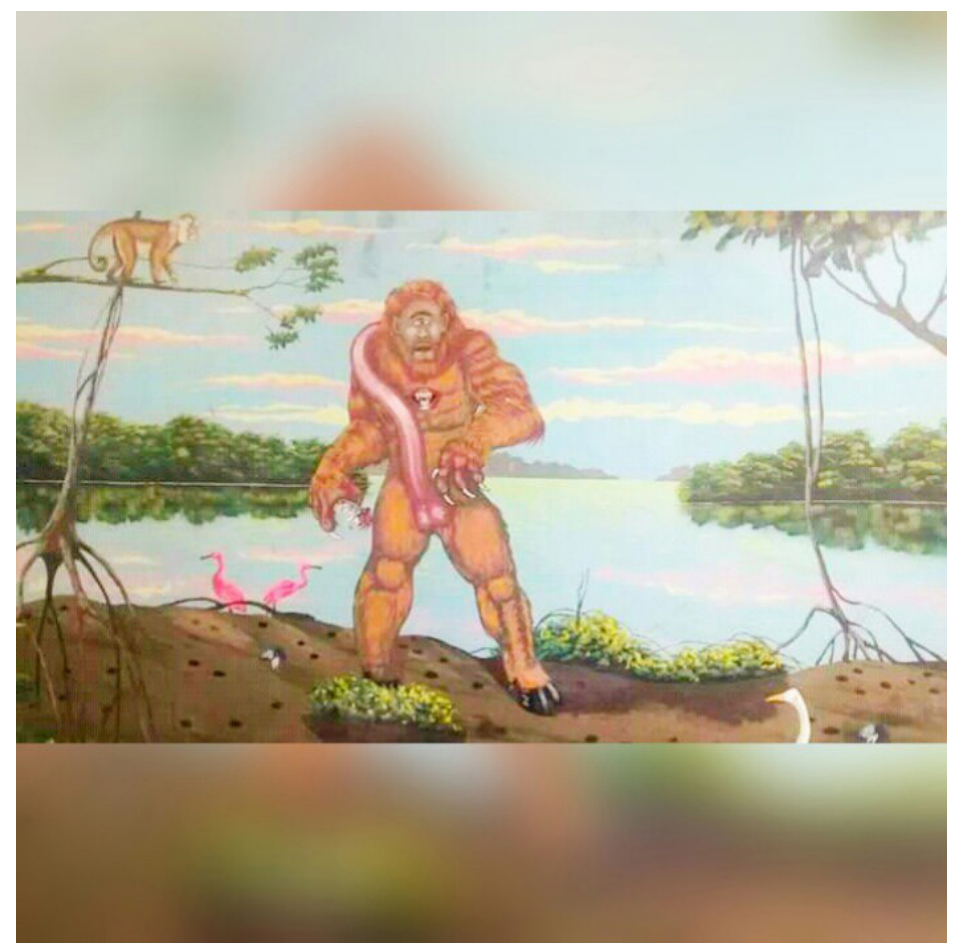

Fonte: arquivo de Moacir de Pinheiro Cardoso Filho (2013)

Na ocasião, inúmeros sites repercutiram a pintura e durante certo tempo enquetes e debates ocuparam as redes sociais, principalmente o Facebook, onde os internautas contrários à obra desenvolveram argumentos baseados na preocupação com o impacto que a imagem teria na "cabeça das crianças", além do "desrespeito às famílias, que não são obrigadas a ver isso", em contraposição com outros usuários da rede que receberam a pintura como algo positivo para a "cultura local" e a "valorização das lendas e patrimônios de Bragança". ${ }^{20}$

Abordada na tese de doutorado de Daniely Meireles do Rosário, a polêmica envolvendo a pintura de Ataíde é interpretada como uma reação de certa moral cristã, mais exatamente no que concerne ao fato de estarem escandalizados com o "tamanho do órgão sexual da pintura" (Rosário 2019:265-271). Segundo o próprio Moacir Filho,

Tem duas formas de se ver o Ataíde, no meu entender, é um ser extraterrestre colocado ali numa nave para coletar os coletores, e tem a questão lendária de proteger a profundidade do mangue e evitar os acessos aos manguezais [...]. 
O Ataíde, pra mim, é algo real e irreal [...] no caso da pintura do Ataíde, eu pensei em pintar o Ataíde e contrariar a sociedade com isso, então botei um falo dele enorme, representando um turu, e na mão do Ataíde tem um caranguejo, né? Na verdade, aquele Ataíde está representando as duas economias do manguezal.

As pinturas de Moacir Filho sobre o Ataíde sofrem mudanças de estilo e de interpretação e, apesar de não nos determos em suas experiências religiosas, é fundamental destacarmos que o artista reconhece nas suas pinturas um tipo de enlace com a espiritualidade que desenvolve, na medida em que tais imagens permitem o diálogo com as forças "místicas".

Figura 16. Pintura do Ataíde em estilo "cubista". A mobilidade de Ataíde pelas árvores, servindo-se do falo, seria uma forma de surpreender os coletores de caranguejo no mangue

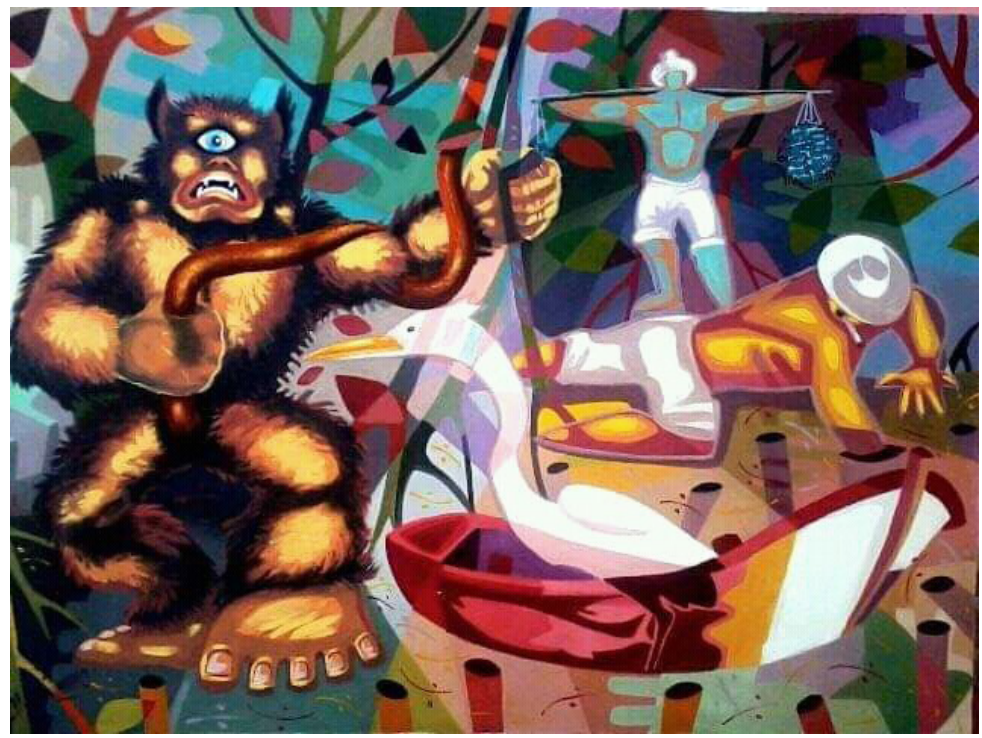

Fonte: arquivo de Moacir de Pinheiro Cardoso Filho (s/d)

A interpretação do Ataíde como uma entidade extraterrestre, colocada no mangue para capturar pessoas, é menos recorrente e parece fazer parte do processo de reconstrução do ser em versões alternativas recentes, entretanto, o "Ataíde Extraterrestre", convém ressaltar, permaneceria ainda dotado de afinidades predatórias no mangue. Esta versão mantém a assertiva de que foi colocado ali para "coletar os coletores" de caranguejos, um tipo de predador de predadores. Neste enredo variante, o órgão sexual é responsável pela descida da "nave" para habitar o mangue. Mundos interligados pelos (e) feitos do "pau-turu"! 


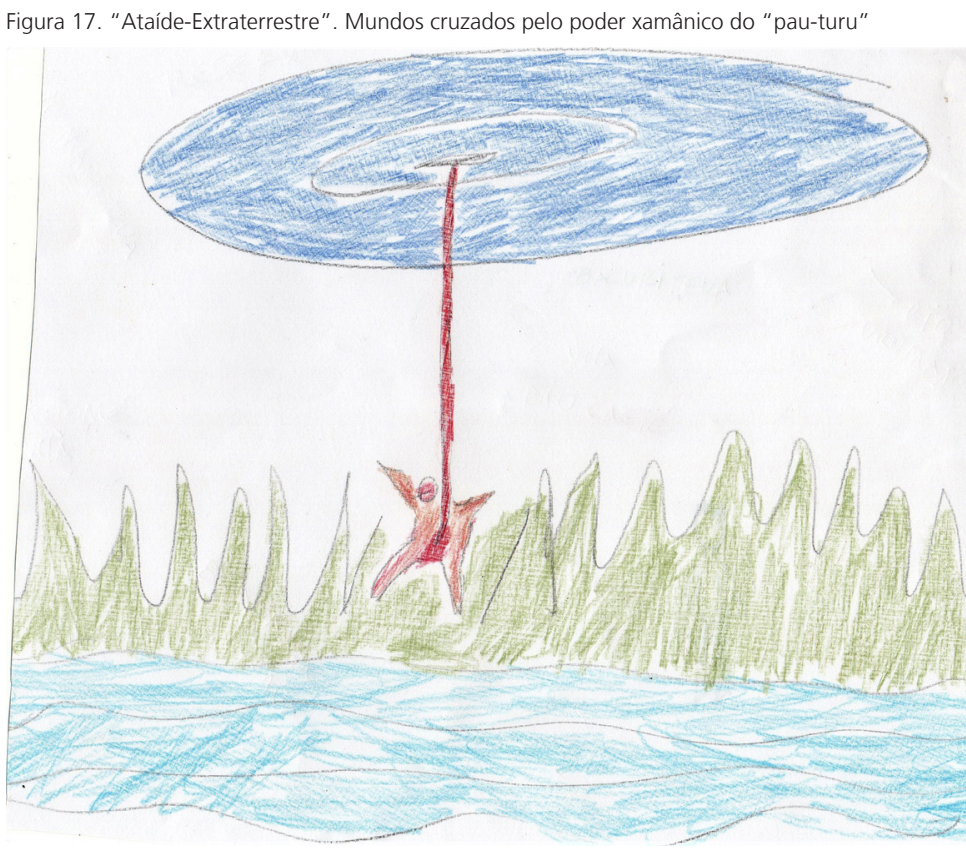

Fonte: rascunhos da pesquisa (2019)

\section{O "xiri": considerações finais}

Pesquisar sobre as cosmologias do Caboclo Ataíde no nordeste paraense significa, antes de tudo, escrever sobre um aspecto da encantaria capaz de atravessar inúmeras possibilidades temáticas e interpretativas. Tudo o que foi apreendido na etnografia realizada, pela diminuta quantidade de pesquisas sobre o tema, torna-se sobretudo um chamamento para novas problematizações.

Envoltos em contextos de interdições de práticas econômicas e sociais, os processos de proteção e cura tornam-se, para o recorte em tela, o símbolo de nosso próximo-distante. Não é inoportuno lembrar que alguns relatos reportam a origem da entidade a um tempo pretérito quando um determinado "caboclo" ou "negão pescador" saciava e era saciado pelos desejos mais íntimos de homens e mulheres, sendo banido da cidade em virtude de seus prodígios.

Se seguirmos o relato sobre o banimento do Ataíde para o mangue, testemunharemos dois tipos de transfiguração: primeiro, fez do homem um encantado, possuidor de redobrado potencial predatório; segundo, permitiu revestir os lugares com sua aura encantatória nos labirintos de mangue, 
mescla ambígua de água (doce/salgada) e terra, que, embora localizados à distância, com um fortuito relance de olhos no horizonte do rio Caeté, seriam reavivados dentro de si como fulguração do mysterium nas paisagens (Cormier 2005:129-154).

Conforme visto, se o fato de Ataíde não estar associado às "cordas" das entidades doutrinadas ou amansadas constitui um impedimento para sua descida nos terreiros, por outro, o torna capaz de interagir num plano onde a maioria das entidades não o faz, isto é, no espaço das entidades "desalinhadas" ou "brabas", nos lugares transgressores habitados pelos moradores. Para analisar melhor essa faceta, a título de finalização, evocaremos rapidamente o papel do "xiri".

A etnografia sobre a entidade foi assenhoreada originariamente pela ação do Ataíde enquanto um enrabador de "cu", o que permite discutir os vários significados e as orientações que a relação primordial "cu" e "pica" assumiram quando entrelaçados estrategicamente ao "xiri" nos três momentos da etnografia.

Primeiro, na versão de um Ataíde que se manifesta no corpo feminino para seduzir e enrabar mediante o "xiri" irresistível que "chama a pica" da vítima, há um tipo de enfeitiçamento, contendo um componente anestésico, que permite que a pica em forma de rabo penetre no incauto, aprisionando o corpo.

Segundo, as raras exceções em que o encantado sai do mangue e adentra os povoados têm como objetivo seduzir as mulheres dos trabalhadores ausentes, marcando uma interface da entrada dos homens no mangue e a entrada do Caboclo na localidade desguarnecida, uma espécie de contrapartida na política cosmológica de especiação, uma extração do lado humano versus uma fecundação do não humano. A entidade assedia o leito sob a aparência física do cônjuge, e é tão somente durante a penetração que a entidade revela suas características, a envergadura do falo o entrega; dito de outro modo, é no invólucro do "xiri" da "vítima" que a armadilha se manifesta. O "xiri", na versão feminina do Ataíde, tem o papel de encobrir e, na versão masculina de um Ataíde que mantém relações sexuais com as mulheres da comunidade, a de desvelar pela dimensão do falo.

Terceiro, o "xiri" é posicionado no sistema de cura e adoecimento como motivo de ressentimento e inveja que aciona o jogo das acusações no interior da comunidade, como no caso da jovem atendida pelo pajé Edvaldo. Entretanto, este portal não é uma via de mão única, pois remete à relação terapêutica acionada pelo "cabaço-amansador" contra o tormento provocado pelo "arpão de arraia" no pescador, apresentado na parte inicial deste texto. Veja-se, um "cabaço" não é um "xiri". O "cabaço" emerge em 
contexto amazônico envolto na mística de um portal fechado, promessa de conexões, enquanto o "xiri" - desdobramento transformacional do "cabaço" -, é consubstanciado para o "cu" e a "pica".

Ainda que pareça estranho, optamos por encerrar o texto pelo "xiri" justamente para sublinhar que não há possibilidade de se pensar e de viver o corpo, a religiosidade e as volições gerais da cultura no contexto amazônico sem nos apercebermos dos arranjos de que são capazes. O "xiri", tão cobiçado no mundo heteronormativo das capas de revistas, sites pornôs e chistes cotidianos, guarda e anuncia a sua diferença no "cu" e na "pica", sabotando internamente o monoteísmo do prazer de determinadas visões de mundo.

Enrabar, nestes termos, nada tem a ver com "xiri", "cu" e "pica", antes pode ser definido como potencialização da vida, estética de acoplagem. Nesta abordagem, a porosidade entre cura, prazer e encantaria no nordeste paraense, de repente, pode nos auxiliar e confortar: auxiliar a combater os preconceitos calcados numa visão de corpo rígida, inflexível, e confortar em saber que, apesar das práticas de silenciamento exercidas sobre corpos que não se sujeitam à camisa de força do binômio masculino-feminino, sempre haverá um Caboclo Ataíde emergindo com a arte do enrabamento de onde menos se espera. Axé!

Recebido em 20/04/2020

Aprovado em 20/02/2021

Jerônimo da Silva e Silva

Doutor em Antropologia pela Universidade Federal do Pará (PPGA), Pósdoutorado no Programa de Pós-Graduação em Sociologia e Antropologia (PPGSA/UFPA). Professor Adjunto na Faculdade de Educação do Campo (FECAMPO), no Programa de Pós-Graduação em História (PPGHIST) e no Programa de Pós-Graduação em Dinâmicas Territoriais e Sociedade na Amazônia (PDTSA). Atua no campo da História e Antropologia da Religião, particularmente da Encantaria Amazônica, Cristianismos, Cosmologias Afroindígenas. Dedica-se nos últimos tempos também ao estudo de Memórias no âmbito da Educação do Campo, Campesinato e Movimentos Sociais na Amazônia. Coordenador Geral do Núcleo de Ações Afirmativas, Diversidade e Equidade (NUADE/UNIFESSPA).

https://orcid.org/0000-0001-7611-4790

E-mail: jeronimosilva@unifesspa.edu.br 
Flávio Leonel Abreu da Silveira

Doutor em Antropologia Social pela Universidade Federal do Rio Grande do Sul, Pós-doutorado em Antropologia (UFRGS). É professor Associado II da Universidade Federal do Pará e docente do Programa de Pós-Graduação em Sociologia e Antropologia (PPGSA). Atua especialmente nos campos de Antropologia da Paisagem, com ênfase nas discussões sobre Cidade, Memória, Imaginário, Patrimônio e Ruína. Atualmente dedica-se ao estudo das relações entre humanos e não humanos na Amazônia. É autor de diversos artigos e capítulos de livros. Bolsista de produtividade do CNPq.

https://orcid.org/0000-0001-9421-5966

E-mail: flabreu@ufpa.br

\section{Notas}

1 Antônio Silva, 35 anos, vendedor de peixe. As arraias são peixes cartilaginosos marinhos, dulciaquícolas e de ambiente salobro, com formação achatada. $\mathrm{Na}$ Amazônia, vivem no fundo dos rios de água doce e são temidas pelo "ferrão" ou "espora" localizado na cauda, agindo, quando ameaçadas, em forma de chicote.

2 As narrativas apresentam a entidade de forma variada, como "caboclo" e "encantado", por exemplo, mas sem guardar diferenciação alguma de maneira mais detida. No texto usaremos os termos alternadamente, sempre com o mesmo sentido.

3 Copaíba é o nome de uma planta utilizada para fins terapêuticos no trato de infecções, ferimentos e incisões abertas, extremamente eficaz quando seu "óleo" ou "folha" entra em contato com tais inflamações, graças às suas propriedades cicatrizantes.

4 Apesar de visitarem as pessoas nos terreiros e serem vistos na mata e nos rios, os encantados habitam cidades, ou locais de "repouso", denominados de encantaria. Esse coletivo de entidades habita no subsolo, raízes de árvores, areais, formações rochosas, ilhas, fundo de rios e até objetos como cadeiras e livros. Para uma observação desses seres em tal complexo cosmológico na Amazônia, indicamos Figueiredo (1982), Silva (2011), Maués (1995), Vergolino-Henry (2008), Figueiredo (2008), Wawzyniak $(2003,2008)$ e mais recentemente a etnografia em um terreiro de Mina Nagô na Amazônia, realizada por Hermes de Sousa Veras (2015).

5 Segundo Maués (1990:196), são "seres que normalmente permanecem invisíveis aos nossos olhos, mas não se confundem com espíritos, manifestando-se de modo visível sob forma humana ou de animais e fazendo sentir sua presença 
através de vozes e outros sinais (como o apito do curupira, por exemplo). Além disso, incorporam-se nos pajés e nas pessoas que têm o dom para a pajelança. Entre os encantados, os do fundo são muito mais significativos para os habitantes da região. Habitam nos rios e igarapés, nos lugares encantados onde existem pedras, águas profundas (fundões) e praias de areia, em cidades subterrâneas e subaquáticas, sendo chamado de encante o seu lugar de morada".

6 O conceito de xamanismo tem sido repensado em outras obras para além de formulações generalistas associadas a êxtases e viagens espirituais. Neste caso, entretanto, buscamos enfatizar apenas alguns aspectos indicados por Eliade (1960:45), quando assinala que "el candidato se trueca em um hombre meditativo, busca la soledad, duerme mucho, parece ausente, tiene sueños proféticos $y$, a veces, ataques. Todos estos sintomas no son más que el prelúdio de la nueva vida que espera, sin saberlo, al candidato [...] Pero se dan también 'enfermedades', ataques, sueños y alucinaciones que deciden en poco tiempo la carrera de um chamán". Embora o mesmo tenha sido posto em recortes etnográficos mais específicos há algum tempo nos estudos de Lagrou (1996:197-232), Gallois (1996:39-74) e Cesarino (2011).

7 As relações dia e noite, claridade e escuridão, penumbra e visibilidade são evocadas como um campo de sensações alternadas e variáveis comunicadas entre humanos e encantados (Durand 2004; Ingold 2012; Rocha \& Eckert 2005).

8 Interdições acerca de horários e calendários para determinadas atividades estão associadas aos humores, às substâncias e às temperaturas do corpo do atingido. Para o caso do corpo feminino, ver Peirano (1975); Rabelo, Alves e Souza (1999); e Motta-Maués (1993).

9 O turu é um molusco que vive no interior de árvores caídas em decomposição. Com a grossura de um dedo e extremamente gelatinoso, é bastante consumido pela população local, sendo também considerado um potente revigorante sexual.

10 Neste relato, optamos por utilizar nomes fictícios.

11 O desaparecimento de pessoas (sequestro) seria uma ação dos encantados. Existem casos de pessoas que podem ser "mundiadas" ou levadas definitivamente para aprender os poderes do fundo, ou mesmo, tornarem-se encantados (Maués 1995).

12 "Devir é nunca imitar, nem fazer como, nem se conformar a um modelo, seja de justiça ou verdade. Não há um termo do qual se parta, nem um ao qual se chegue ou ao qual se deva chegar. Tampouco termos intercambiantes. A pergunta 'o que você devém?' é particularmente estúpida. Pois à medida que alguém se transforma, aquilo em que ele se transforma muda tanto quanto ele próprio. Os devires não são fenômenos de imitação, nem de assimilação, mas de dupla captura, de evolução não paralela, de núpcias entre dois reinos" (Deleuze 1998). Nesse sentido, Devir é um conceito do universo de leitura do pesquisador, estratégia para simetrizar as dificuldades, entretanto, todos os conceitos enfrentam devires imediatamente na apropriação do campo de pesquisa, assim, trata-se mais de locução embebida pela experiência da pesquisa de campo com as núpcias da etnografia. 
13 "Aparelho", "casco", "formatura", "peito" e "caixa" são alguns termos locais utilizados pelos narradores para descrever o corpo de uma pessoa acometida pela incorporação dos encantados.

14 Se as "linhas" ou "cordas" são os grupos de entidades alojados no corpo do iniciante, a "viração" é a capacidade de passar de uma "corda" à outra e, assim, de acionar especificidades na prática da cura e combate a feitiços (Silva 2014, 2018). Embora não se generalize, outras pesquisas guardam aproximações (Galvão 1975; Ferretti 2000; Negrão 1996; Quintas 2007).

15 Castigos físicos aplicados pelas entidades, formas de repreensão com finalidade de aprimoramento do "dom".

16 Entidade espiritual ou ser incorpóreo que acompanha o corpo de alguns médiuns, pessoas com peito aberto, com dons ou vítimas de feitiços/"bandalheiras".

17 Flechas é termo utilizado para designar certa propriedade em forma de doença, feitiço ou encantamento lançados por seres da encantaria sobre transeuntes desprevenidos (flechadas, mau-olhado, maldade dos espíritos). Ver Maués (1990) e Nobre (2009).

18 Os usos desses termos variam, mesmo no interior do que chamamos de "maldade" (Novaes 1997:81-106; Maggie 1992; Bahia 2011).

19 Disponível em: https://g1.globo.com/pa/para/noticia/2018/12/13/desenhode-lenda-amazonica-com-penis-gigante-causa-polemica-no-interior-do-para.ghtml Acesso em 16/07/2019.

20 Disponível em: https://www.facebook.com/jhony.cley.12/ posts/767998526886989 Acesso em 14/03/2019. 


\section{Referências bibliográficas}

BAHIA, Joana. 2011. O tiro da bruxa: identidade, magia e religião na imigração alemã. Rio de Janeiro: Garamond.

BARBOSA NETO, Edgar. 2012. A Máquina do Mundo: variações sobre o politeísmo em coletivos afro-brasileiros. Tese de Doutorado. Museu Nacional, Rio de Janeiro.

BERQUE, Augustin. 1998. "Paisagemmarca, paisagem-matriz: elementos da problemática para uma geografia cultural". In: R. Corrêa \& Z. Rosendhal (orgs.), Paisagem, tempo e cultura. Rio de Janeiro: EdUERJ. pp. 84-91.

CESARINO, Pedro. 2011. Oniska: poética do xamanismo na Amazônia. São Paulo: Perspectiva/Fapesp.

CORMIER, Loretta. 2005. "Um aroma no ar: a ecologia histórica das plantas antifantasma entre os Guajá da Amazônia". Mana, 11 (1):129-154.

DELEUZE, Gilles. 1998. Diálogos com Claire Parnet. São Paulo: Escuta.

DÍAZ-BENÍTEZ, María Elvira. 2019. "O gênero da humilhação. Afetos, relações e complexos emocionais". Horizontes Antropológicos, 54:51-78.

DOMINGUES, Bruno Rodrigue. 2019. Entre Tradição, Desejo e Poder: uma Amazônia cosmoerótica. Trabalho de Conclusão de Curso, Universidade Federal do Pará, Belém.

DURAND, Gilbert. 2004. "O retorno do mito: introdução à mitodologia. Mitos e Sociedades". Revista Famecos, Porto Alegre, 23:7-22.

ELIADE, Mircea. 1960. El chamanismo y las técnicas arcaicas del éxtasis. Ciudad de México: Fondo de Cultura Económica.

FARES, Josebel. 1997. Imagens da mitopoética amazônica: um memorial das matintas pereras. Dissertação de Mestrado, Universidade Federal do Pará, Belém.

FERRETTI, Mundicarmo. 2000. Desceu na guma: o caboclo do Tambor de Mina em um terreiro de São Luís - a Casa Fanti-Ashanti. São Luís: Edufma.

FIGUEIREDO, Arthur Napoleão. 1982. Todas as divindades se encontram nas "encantarias" de Belém. In: A. Pellegrini Filho, Antologia do Folclore Brasileiro. São Paulo: EDART. pp. 109-111.

FIGUEIREDO, Aldrin. 2008. A cidade dos Encantados: Pajelança, feitiçaria e religióes afro-brasileiras na Amazônia. Belém: Edufpa.

FIGUEIREDO, Marina. 2012. "Das participações míticas: reflexões sobre o perspectivismo e o axé". 36 Reunião Anpocs, Águas de Lindoia, $\mathrm{s} / \mathrm{n}$.

GALLOIS, Dominique. 1996. "Xamanismo waiãpi: nos caminhos invisíveis, a relação i-paie". In: E. Langdon (org.), Xamanismo no Brasil: novas perspectivas. Florianópolis: Editora UFSC. pp. 39-74.

GALVÃO, Eduardo. 1975. Santos e Visagens: um estudo da vida religiosa em Itá, Amazonas. São Paulo: Cia. Editora Nacional.

GOLDMAN, Márcio. 2005. "Formas do Saber e Modos do Ser. Observações sobre Multiplicidade e Ontologia no Candomblé". Religião e Sociedade, 25 (2):102-120.

INGOLD, Tim. 2012. "Caminhando com dragões: em direção ao selvagem". In: A. C. Steil \& I. C. Carvalho (orgs.), Cultura, percepção e ambiente: diálogo com Tim Ingold. São Paulo: Ed. Terceiro Nome. pp. 7-13. 
LAGROU, Elsje. 1996. "Xamanismo e representação entre os Kaxinawá". In: E. Langdon (org.), Xamanismo no Brasil: novas perspectivas. Florianópolis: Editora UFSC. pp. 197-232.

LATOUR, Bruno. 1994. Jamais fomos modernos: ensaio de antropologia simétrica. Rio de Janeiro: Ed. 34.

LIMA, Tânia. 1996. "O dois e seu múltiplo: reflexões sobre o perspectivismo em uma cosmologia Tupi". Mana, 2 (2):21-47.

MAGGIE, Yvonne. 1992. Medo do feitiço: relações entre magia e poder no Brasil. Rio de Janeiro: Arquivo Nacional.

MATOS, Alessandra. 2001. Vocabulário Semi-sistemático da Terminologia do Caranguejo. Dissertação de Mestrado, Programa de Pósgraduação em Letras, Belém, UFPA.

MAUÉS, Raymundo Heraldo. 1990. A ilha encantada: medicina e xamanismo. Belém: Universidade Federal do Pará.

MAUÉS, Raymundo Heraldo. 1995. Padres, Pajés, santos e festas: catolicismo popular e controle eclesiástico. Um estudo antropológico numa área do interior da Amazônia. Belém: Cejup.

MOTTA-MAUÉS, Maria Angélica. 1993. "Trabalhadeiras" e "Camarados": relações de gênero, simbolismo e ritualização numa comunidade amazônica. Belém: Centro de Filosofia e Ciências Humanas/UFPA. NEGRÃO, Lísia. 1996. Entre a Cruz e a Encruzilhada: Formação do Campo Umbandista em São Paulo. São Paulo: Edusp.

NOBRE, Angélica. 2009. Atravessando fronteiras: viagem rumo à saúde tradicional. Tese de Doutorado em Ciências Sociais, UFPA, Belém.

OLIVEIRA, Marcos Vinícius. 2015. A estrada para o "progresso": política, cultura e natureza em Bragança, Pará (1970-1996). Dissertação de Mestrado em História, UFPA, Belém.

OLIVEIRA, Kátia Regina Morais; REIS, Maiara da Silva \& SANTOS, Raquel Amorim. 2018. "Representação do Mito do Ataíde nas Vozes de Crianças na Comunidade Ribeirinha do Castelo em Bragança-PA". @rquivo Brasileiro de Educação, 14:62-87.

PEIRANO, Mariza. 1975. Proibições Alimentares numa comunidade de Pescadores. Dissertação de Mestrado em Antropologia, UnB, Brasília.

PEREZ，Ariadne. 2011. Estudo antropológico de uma comunidade na abrangência da Reserva Extrativista Marinha Caeté-Taperaçu (BragançaPará-Brasil). Tese de Doutorado, Universidade Federal do Pará, Belém.

QUINTAS, Gianno. 2007. Entre maracás, curimbas e tambores: pajelanças nas religiões afro-brasileiras. Dissertação de Mestrado, Universidade Federal do Pará, Belém.

ROCHA, Ana Luíza \& ECKERT, Cornélia. 2000. "Os jogos da memória". Ilha, 1:71-84.

ROSÁRIO, Daniely Meireles. 2019. Entre a lona e a parede urbana: a outra face da pintura paraense pela obra de Moacir Cardoso. Tese de Doutorado, Universidade Federal de Minas Gerais, Belo Horizonte.

SARRAF-PACHECO, Agenor. 2009. En el corazón de la Amazonía: identidades, saberes e religiosidades no Regime das Águas Marajoaras. Tese de Doutorado, Pontifícia Universidade Católica de São Paulo, São Paulo.

SILVA, Jerônimo. 2011. “No Ar, na Água e na Terra": Uma Cartografia das Identidades nas Encantarias da "Amazônia Bragantina". Dissertação de Mestrado, Universidade da Amazônia, Belém. 
SILVA, Jerônimo. 2014. Cartografia de Afetos na Encantaria: narrativas de mestres na Amazônia Bragantina. Tese de Doutorado, Universidade Federal do Pará, Belém.

SILVA, Jerônimo. 2018. Tarrafa, Anzol \& Flecha: tecnologia Xamânica de predação entre humanos e encantados no nordeste paraense. Revista Anthropológicas, 29(1): 28-57.

SILVA, Alessandra; CARDOSO, Savana Cristina \& PINHEIRO, Luciana. 2014. "O lugar dos seres encantados e dos saberes acadêmicos: o realismo maravilhoso em narrativas orais da região bragantina". A Palavrada, 5:10-25.

SILVA, Joel Pantoja. 2019. Patrimônios, narrativas e encantaria no Marajó. Tese de Doutorado, Universidade Federal do Pará, Belém.

SILVEIRA, Flávio Leonel. 2005. “Da etnografia como experiência à antropologia histórica e por imagens". In: J. Martins; C. Eckert \& S. Novaes (orgs.), O imaginário e o poético nas Ciências Sociais. Bauru: EDUSC. pp. 255-270.

SILVEIRA, Flávio Leonel \& SOUZA, Camila. 2014. "Imaginário, trabalho e sexualidade entre os coletores de caranguejo do Salgado Paraense". Estudos Feministas, Florianópolis, 22 (3):755-780.

SIQUEIRA, Deis Elucy. 2013. "Civilização do mangue: biodiversidade e populações tradicionais". Horizonte, 11:509-544.

SOUZA, Camila. 2013. Relações de Gênero em Bacuriteua (PA): imaginário do homoerotismo masculino entre coletores de caranguejo. Dissertação de Mestrado, Universidade Federal do Pará, Bragança.

TRINDADE, Raída. 2007. "Aqui, a cura é de verdade": Reflexões em torno da Cura Xamânica em São Caetano de Odivelas-PA. Dissertação de Mestrado, Universidade Federal do Pará, Belém.

VERAS, Hermes. 2015. O sacerdote e o aprendiz: etnografia, experiência e ritual em um terreiro de Mina Nagô na Amazônia. Dissertação de Mestrado, Universidade Federal do Pará, Belém.

VERGOLINO-HENRY, Anaíza. 2008. “Um encontro na encantaria: notas sobre a inauguração do 'Monumental Místico Rei Sabá'". In: R. H. Maués \& G. M. Villacorta (orgs.), Pajelanças e religióes africanas na Amazônia. Belém: Edufpa. pp. 139-148.

VILLACORTA, Gisela Macambira. 2000. "As Mulheres do Pássaro da Noite": Pajelança e feitiçaria na região do salgado [nordeste do Pará]. Dissertação de Mestrado, Universidade Federal do Pará, Belém. VIVEIROS DE CASTRO, Eduardo.1996. "Os pronomes cosmológicos e o perspectivismo ameríndio". Mana 2 (2):115-144

WAWZYNIAK, João Valentim. 2003. "'Engerar': uma categoria cosmológica sobre pessoa, saúde e corpo". Ilha, 5 (2):33-55.

WAWZYNIAK, João Valentim. 2008. Assombro de olhado de bicho: uma etnografia das concepções e ações em saúde entre os ribeirinhos do baixo Tapajós, Pará. Tese de Doutorado, Universidade Federal de São Carlos, São Carlos. 
ENRABAMENTO, CURA E

PROTEÇÃO: COSMOLOGIAS DO CABOCLO ATAÍDE NO NORDESTE PARAENSE

\section{Resumo}

O Caboclo Ataíde é uma entidade da encantaria amazônica que se manifesta próximo dos rios e mangues no litoral do nordeste paraense, município de Bragança, conhecido como um "caboclo" ou "encantado" que emerge das narrativas das populações locais sob a forma de animais. O artigo analisa a presença do encantado em dois aspectos. No primeiro, apreende-se o ato de "enrabar" pessoas em ambientes de pesca, retirada de caranguejo e festas, penetrandolhes o "rabo" e "xiri" repentinamente, causando dores e doenças com variados efeitos; o segundo é a capacidade de proteger pessoas acometidas pela "malinação" de outros encantados, sendo evocado por rezadores e pajés da região para combater ou "tirar as cordas" dos chamados "caboclos brabos". Narrativas acerca do ato de enrabar e proteger, alternativamente, visibilizam elementos da relação cosmológica da entidade em variadas formas de afetação nos espaços do trabalho, do prazer e da cura.

Palavras-chave: Enrabamento, Cura, Encantados, Amazônia.

\author{
ENRABAMENTO, HEA LING AND \\ PROTECTION: COSMOLOGIES OF \\ THE CABOCLO ATAÍDE IN THE \\ NORTHEAST OF PARÁ
}

\section{Abstract}

Caboclo Ataíde is an entity of the Amazon enchantment that manifests itself near the rivers and mangroves on the coast of northeastern Pará, mainly in the town of Bragança. He is known as a "caboclo" or an "enchanted" featuring in the narratives of the local populations in the form of different animals. This article analyzes two aspects of the presence of the enchanted: First, through the act of "enrabar" (analizing) people in fishing environments, crab fishing expeditions, and feasts, where one suddenly feels their ass ("rabo" or "xiri") being penetrated, causing pain and illness with different effects; Second, through the ability to protect people affected by the "naughtiness" of other enchanted ones, being summoned by healers and shamans of the region to battle with or "remove the lines" of the so-called "brabos caboclos". Narratives about analizing and protecting show elements of the entity's cosmological relationship in various forms of affectation in the spaces of work, pleasure and healing.

Key words: Enrabamento, Cure, Enchanted, Amazon. 


\section{ENRABAMENTO, SANACIÓN Y \\ PROTECCIÓN: COSMOLOGÍAS \\ DEL ATAÍDE DE CABOCLO EN EL NORDESTE DE PARÁ}

\section{Resumen}

El Caboclo Ataíde es una entidad de la encantaría amazónica que se manifiesta cerca de ríos y manglares en el municipio de Bragança en la costa del nordeste de Pará. Es conocido como un "caboclo" o "encantado" que surge en las narraciones de pobladores locales en forma de animales. El artículo analiza la presencia de los encantados en dos aspectos, siendo el primero el acto de "enrabar" a las personas en entornos de pesca, durante la retirada de cangrejos y/o en celebraciones, la persona es detenida y penetrada repentinamente por la "cola" y "xiri", causándole dolor y enfermedad con diferentes efectos; el segundo es la capacidad de proteger a las personas afectadas por las "travesuras" de otros encantados, siendo en ocasiones evocados por rezos y chamanes de la región para luchar o "eliminar las líneas" de los llamados "caboclos brabantes". Las narrativas sobre el acto de avergonzar y proteger a las personas alternativamente, muestran elementos de la relación cosmológica de la entidad a partir de diversas formas de afectación en los espacios de trabajo, placer y curación.

Palabras clave: Enrabamento, Cura, Encantados, Amazonía. 